\title{
On the Structure and Relationships of Trigonocarpus Shorensis, sp. nov.
}

\author{
A New Seed from the Palaeozoic Rociks. ${ }^{1}$
}

\author{
BY \\ E. J. SÄLISBURY, B.SC.., F.L.S. \\ Lecturer in Botany, East London College, University of London.
}

With Plates IV and V and eight Figures in the Text.

\section{CONTENTS.}

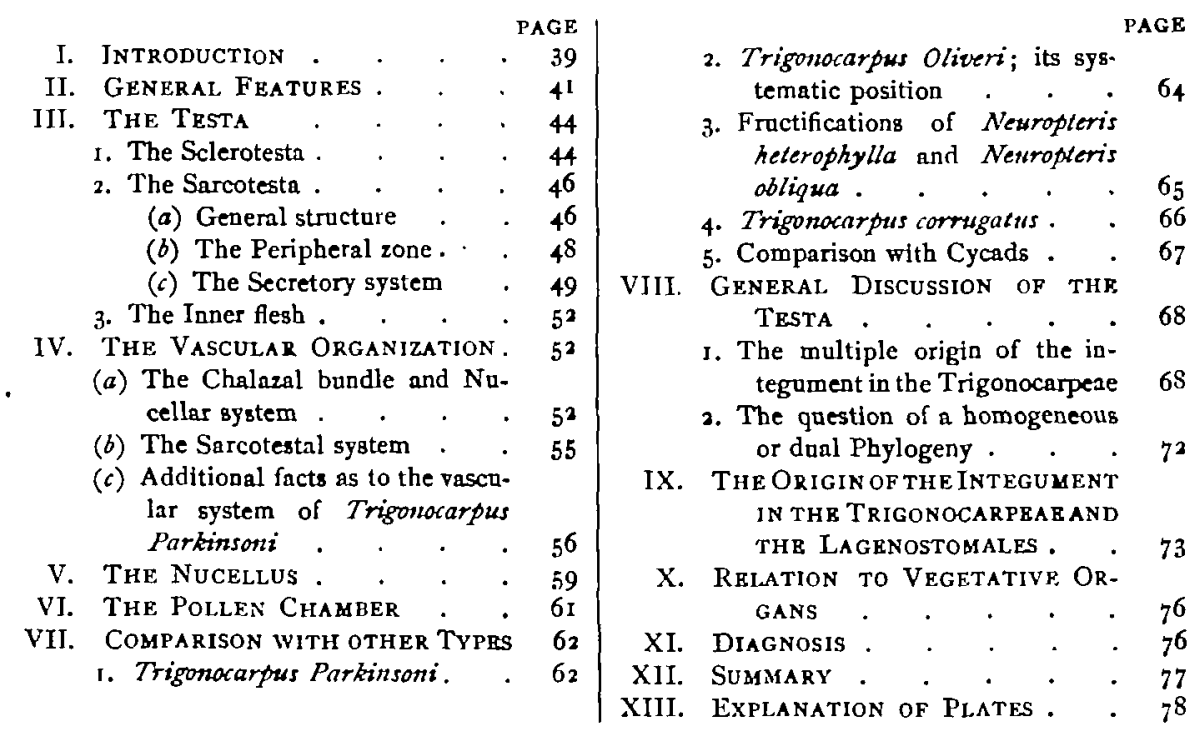

\section{INTRODUCTION.}

$\mathrm{T}$

HE bulk of the material which forms the basis of this communication was placed in my hands for investigation by Prof. F. W. Oliver; and I gladly take this opportunity of expressing my deep indebtedness to him for much helpful advice and criticism, and also for putting at my disposal such slides of the University College Collection as I have had occasion to consult.

1 Thesis approved for the degree of Doctor of Science in the University of London.

[Annals of Botany, Vol. XXVIII. No. CIX. Jannary, I914.] 


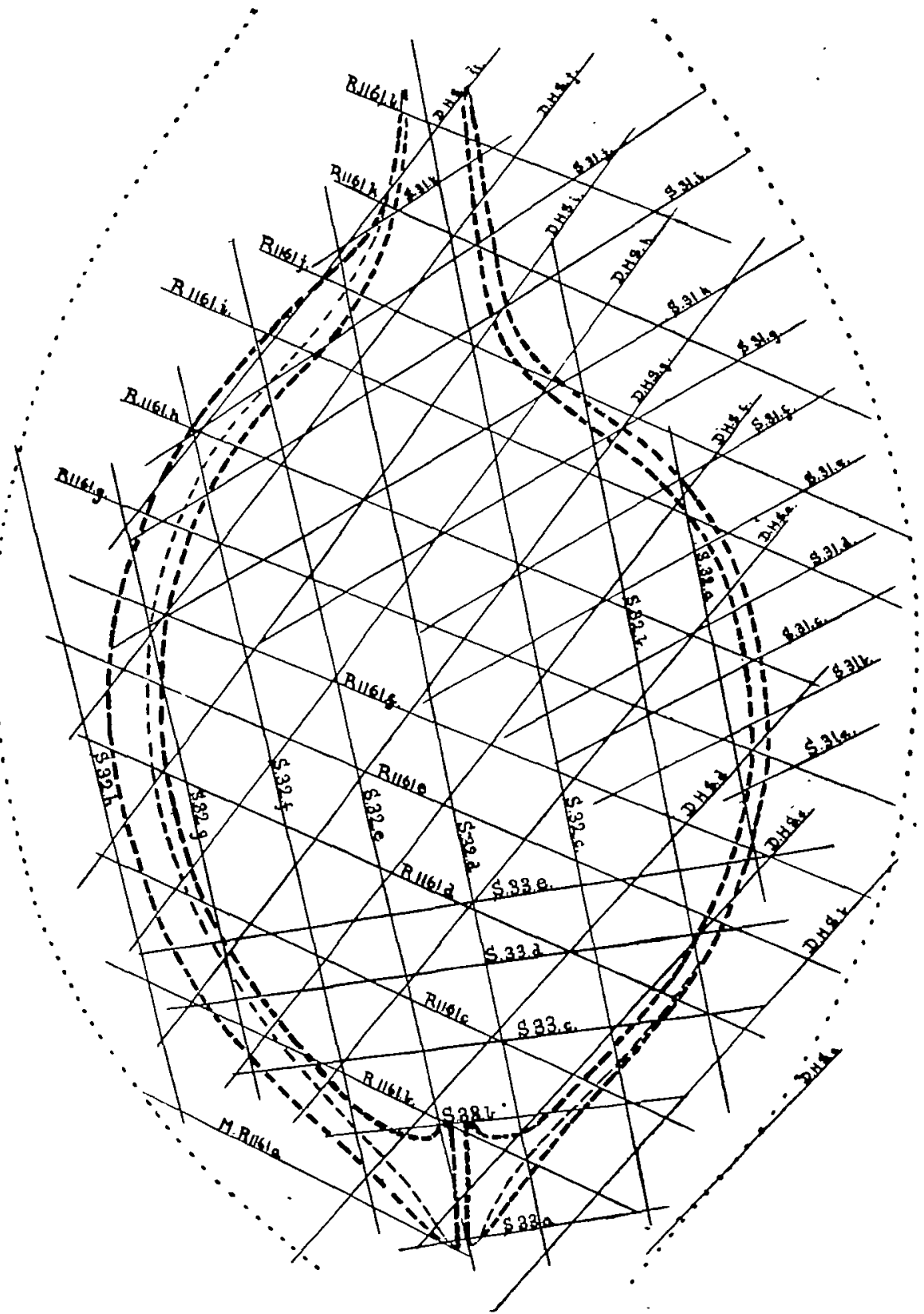

TEXT-FIG. I. Plottings on an ideal median longitudinal section ghowing the planes of all the preparations. D.H.S. - Dr. Scott's series; R. = Owens College, Manchester, series ; s. = University College, London, Collection. 
My thanks are also due to Dr. D. H. Scott and to Prof. F. E. Weiss for the loan of preparations. To Dr. Scott I am also indebted for permitting me to examine the more important sections in his unique collection of Trigonocarpus Parkinsoni, without which an adequate comparison between the two seeds would not have been possible.

The same methods have been employed in the reconstruction of the present seed as were used in the investigation of Conostoma oblongum and C. anglo-germanicum. ${ }^{1}$ These have been recently described in a separate article ${ }^{2}$ and need not be recapitulated here.

The sections that furnish data for the following account are all cut from seam nodules obtained from the well-known locality at Shore Littleborough, re-opened through the generosity of the late Mr. Sutcliffe. To mark its origin it has been thought appropriate to designate this seed by the specific name of Shorensis.

\section{General features.}

The seed with which the present investigation deals was of large size, approximately elliptical in form, and circular in transverse section. The exact limits at either end cannot with certainty be determined, but the total length was probably considerably over four centimetres. In breadth the seed attained a maximum diameter, about half-way up, of nearly two and a half centimetres.

Although specimens showing the actual attachment of the seed are wanting, the chalazal end certainly tapered towards its insertion and, judging from the general direction of the surface curvature, followed a more gentle curve inwards to the appex.

The testa comprised three or perhaps four layers, the two outer of which constituted a broad sarcotesta remarkable for the presence of a number of scattered secretory sacs and representing nearly onethird of the total width of the seed.

Within the sarcotesta was a hard sclerized shell bearing three salient ridges

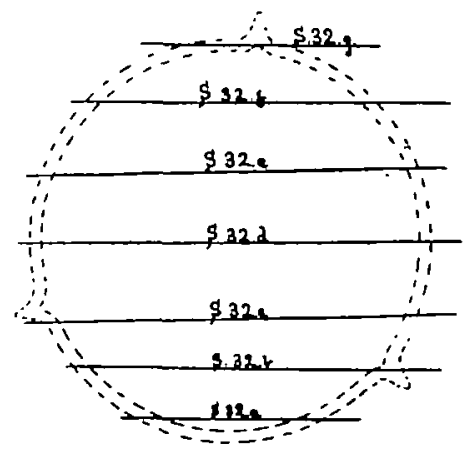

TeXr-FIG. 2. Plottings on the transverse section of the $\mathrm{S}$. 32 sertes. which extended from the base to the apex. 'These ridges were symmetrically placed around the body of the seed, and from the chalazal end to about a third the height of the sclerotestal shell were present three more ribs much less pronounced than the former, and occupying positions intermediate between them.

1 Oliver and Salisbary : On the Structure and Affinities of the Palaeozoic Seeds of the Conostomaa group. Ann. Bot., vol. xxp, 1911.

Ann. Bot., vol, xxvii, No. cri, I9r3. 


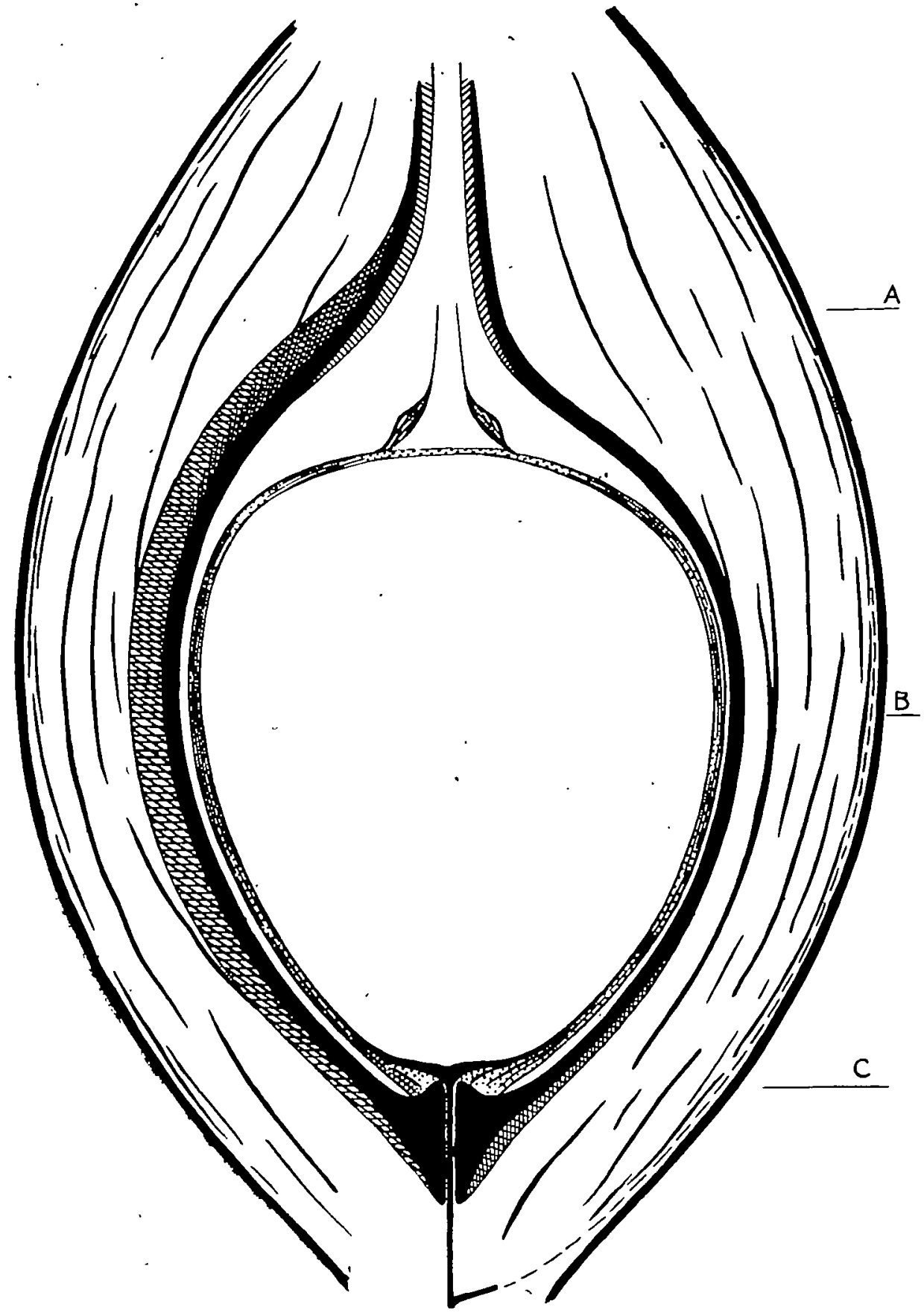

TexT-FIG. 3. Diagrammatic restoration of an ideal median longitudinal section of Trigonocarpus Shorensis passing through a primary and secondary rib. The sclerotesta and limiting layers of the sarcotesta are shown in black; the ribs are cross-hatched, and the inner flesh, the extent of which is hypothetical, is represented by diagonal shading. The branching of the chalazal bundle is based on analogy with T. Parkizsoni, and the direction of one of the sarcotestal strands is also shown as a dotted line, though not actually present in the plane of section. Nucellar tissae dotted, secretory sacs black. 


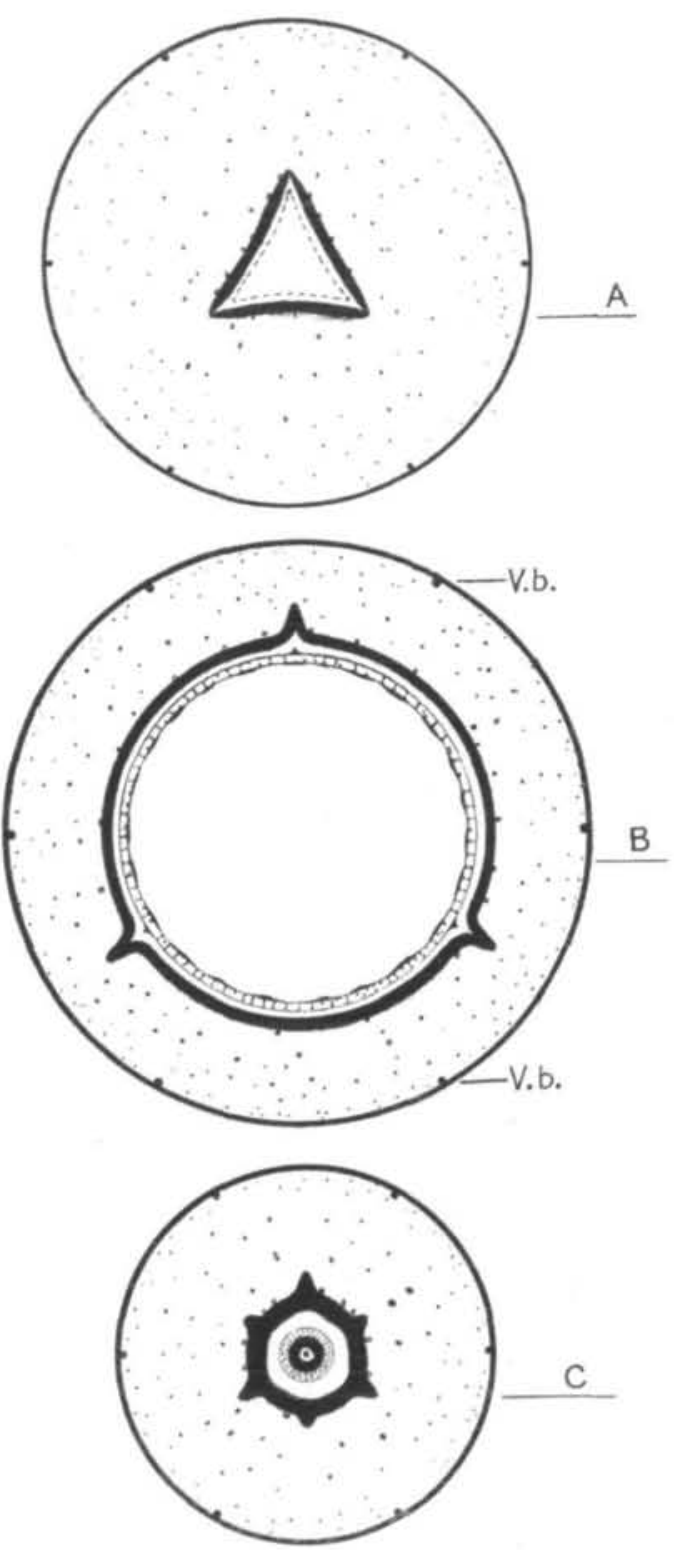

Text-Fig. 4. Transverse restorations of Trigonocarpus Shorensis at the levels A, B, c in Fig. 3. Tissues represented as in the previous diagram. The six sarcotestal strands are represented by large black dots, and the secretory sacs by smaller.

In the chalazal region there were thus six ribs, of which three soon die out, whilst the remaining three persist.

In general form the sclerotesta was ovoid, the pointed end corresponding to the chalazal region, whilst the blunt end was surmounted by a triangular 
micropylar tube, the angles being continuations of the ribs lower down, into which they pass by a hollow curve.

Within the sclerotic tissue was a fourth layer, probably confined to the micropylar region and representing the 'inner flesh' of related seeds.

The megaspore cavity was much less pointed at the base than was the hard shell around, and through this divergence of the two surfaces a chalazal cushion of sclerotic tissue was formed from which arose a nucellus, that stood up erect and free within the seed cavity, surmounted at its apex by a large pollen-chamber.

The nucellus was bounded at the exterior by a well-differentiated epidermis, and within was a tracheal sheath forming the upward continuation of a single vascular strand which pierced the chalazal cushion.

The vascular organisation was essentially similar to that of other seeds of this group, and consisted of a sarcotestal system of bundles without and a nucellar system within.

Neither pollen nor prothallus are preserved in any of our sections, which may indicate that all our specimens were abortive ovules, though the presence of numerous fungal spores within the megaspore cavity may indicate its former occupation by an organized tissue which served as nourishment to the saprophytic organisms.

\section{The TESTA.}

\section{The Sclerotesta.}

The obovoid sclerotesta had an average thickness of about $0.5 \mathrm{~mm}$. and bore, as we have seen, six longitudinal ribs, of which the three major persisted as far as the triangular beak. At the apex these ribs pass gradually into the three angles of the micropyle, and, except at the base, are commissured. The major ribs from the base of the micropyle to within some $6 \mathrm{~mm}$. of the chalazal extremity have about the same radial extent, but exhibit varying development in the different specimens $(0.75 \mathrm{~mm}$. from surface in S. 33, a-e, to $\mathrm{I} \cdot 4 \mathrm{~mm}$. in S. $\left.3^{\mathrm{I}}, a-k\right)$. The three minor ribs alternated with the three major, were without commissures, and attained their greatest extent $(0.4 \mathrm{~mm}$.) about $2 \mathrm{~mm}$. from the base, above which point they gradually diminished and finally died out some $8 \mathrm{~mm}$. from the chalaza. At the base of the seed the sclerotesta formed a solid inverted cone about $3.5 \mathrm{~mm}$. high, perforated by a narrow canal through which the single vascular bundle passed to the floor of the nucellus. The base of this cone projected upwards as a domeshaped papilla about $0.5 \mathrm{~mm}$. high and $1.5 \mathrm{~mm}$. in diameter, and its margin served as the place of attachment for the nucellar epidermis. As the ribs, both major and minor, approached the chalazal end they became gradually smaller till at the extremity all indication of ribbing had disappeared. The cavity within the sclerotesta was, owing to the sclerotic papilla, much blunter 
than the external form, and from the base of the micropylar canal measured some $19 \mathrm{~mm}$. with a diameter in its broadest part of slightly over $14 \mathrm{~mm}$.

Sections through the micropyle (Pl. IV, Fig. 2) show that the sclerized sides of the triangular canal about half-way up, formed of four layers of longitudinally directed fibres, were from 0.13 to $0.14 \mathrm{~mm}$. in thickness and distinctly concave, the internal diameter of the canal measured from the apex of an angle to the middle of one of the sides being just over $2 \mathrm{~mm}$. In the highest of our sections (Pl. IV, Fig. 5), viz. Man. Coll. R. I I6I, $b$, the limit between sclerotesta and sarcotesta is indefinite and the diameter of the micropyle is reduced to $1 \cdot 4 \mathrm{~mm}$. On that side of this oblique section which is at the higher level the sclerized layer is seen to be even less developed than on the lower, and the concavity of the flanks has resolved itself into a slight double convexity (thickness between the angles $0.10 \mathrm{~mm}$. and at the convexities $0.16 \mathrm{~mm}$.) (Pl. IV, Fig. $8, m, c$ ).

Although this section is broken there is evidence that the sclerotesta towards the apex segregated into three distinct portions separated at the angles by intervening soft tissue and each itself composed of two parts fused in the median plane.

Except for the slight local thickening, both here and in the preceding section, there is a thinning down of the sclerotic beak which, if maintained at the same rate, must have resulted in its complete elimination at a level not far above that at which our section was cut.

From these facts it would appear that the beak was comparatively short (probably not more than $8 \mathrm{~mm}$. in length), although the extensive development of the sarcotesta at this level and the curve which successive sections show its surface to have followed indicate a much further persistence of that tissue. So that in this respect our seed resembled most closely the condition that obtains in present-day Cycads.

Histology of the Sclerotesta. The sclerotesta was formed of from $\mathrm{I}_{4}$ to I 5 layers of thickened fibrous elements, of which the inner, and most of those forming the ribs, were longitudinally directed. In the best-preserved specimens the innermost layer is seen to have been composed of radially flattened fibres which form a smooth internal surface, and negative the suggestion of a more interior tissue. In transverse sections the fibres appear rounded or polygonal $(28-42 \mu)$ with dark contents separated by a thin membrane (? middle lamella), on either side of which is a translucent yellow zone about $3.5 \mu$ in width perhaps representing the cell-wall. The fibres consisted of superposed cells which can be traced for over $1 \cdot 5 \mathrm{~mm}$.

The sclerotic fibres, $5 \rightarrow 9$ deep, forming the outer layers behave as aggregates or bands, each of from one to two elements in the radial direction and of a very variable number in the tangential (Text-fig. 5). For a time each band follows the longitude of the seed, and then almost abruptly all the fibres bend, some to the right and others to the left, or all 
of them in the same direction, so that their course is at a very narrow angle with the horizontal plane, and in transverse sections they appear cut obliquely or almost longitudinally for some distance. Where the members of a band are in one layer they appear to all bend in a similar manner, but where the band is more than one element in thickness those of each layer probably bend in opposing directions, but it cannot be definitely ascertained whether or no they again take up a longitudinal direction.

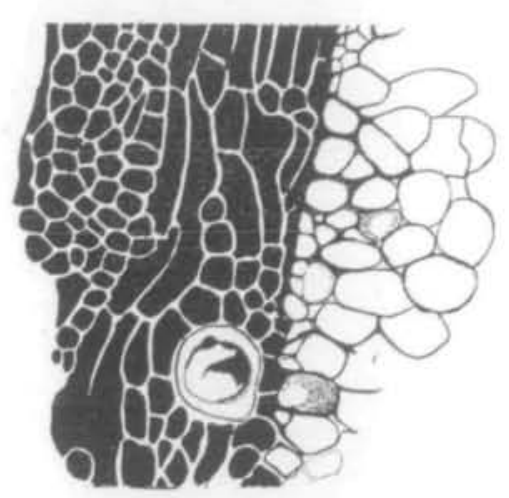

TEXT-FIG. 5. A portion of the sclerotesta as seen in transverse section, showing the vertically directed fibres at the interior and the almost horizontal direction at the periphery; a single secretory sac is also present.

The extreme irregularity of the course of the fibres is shown by the inconstant numerical relation between those cut obliquely and transversely, and, to still further complicate the structure, the bands do not always remain in the same vertical plane.

Owing to this complex interlacing of the outer elements of the sclerotesta, it presents a plait-like appearance when cut by sections tangential to the surface, as is seen in Pl. IV, Fig. 3.

Eventually the thickened elements of the sclerotesta pass obliquely outwards by a well-marked transition into the sarcotesta.

In the outer part of the sclerotesta, and there only, elongated secretory elements partially or entirely immersed in the sclerotic tissue are present, which pass out into the sarcotesta at one point and occasionally into the sclerotesta again at another (Pl. IV, Fig. 6, m.s.). In all respects these secretory elements resemble those present in the sarcotesta.

For convenience of description the sclerotesta has been treated as consisting of two parts, the plane at which the different structure is assumed being variable. There is, in fact, little doubt that the outer zone represents the terminations of a large portion and perhaps even all of the longitudinally directed fibres, and cannot possibly be regarded as the region of fusion of two morphological surfaces, as has been suggested for the stony layer of the Cycadean ovule. ${ }^{1}$

\section{The Sarcotesta.}

(a) General Structure. The sarcotesta in the living state must have been the most pronounced feature of this seed, for even as petrified it invests the sclerotic shell in the middle region to a thickness of over $4 \mathrm{~mm}$.

1 Stopes: The Double Nature of the Cycadean Integument. Ann. Bot., vol. xix, $190_{5}$. 
At the base this decreased to under $2 \mathrm{~mm}$., but the almost sudden concavity of the sclerotesta at the micropyle gives the sarcotesta in that region a maximum thickness of nearly $6 \mathrm{~mm}$. Although our highest sections pass not far below the apex no flattening is exhibited, but the sarcotesta curves inwards equally on all sides. This is in conformity with the impressions of seeds attached to Neuropteris heterophylla and Neuropteris obliqua described by Kidston ${ }^{1}$ and Kidston and Jongmans. ${ }^{2}$

The junction of the sclerotesta with the sarcotesta, composed as the latter was of thin-walled cells, appears superficially as a sudden change, but the innermost cells of the sarcotesta can be recognized as direct continuations of the rows of sclerized elements. It is only in tangential or longitudinal sections that this transition can be properly seen, since the innermost sarcotestal cells, which are elongated and tubular $(0.15 \mathrm{~mm}$.$0.25 \mathrm{~mm} . \times 0.033-0.049 \mathrm{~mm}$.), are directed obliquely outwards and upwards (Pl. IV, Fig. 5). Owing to this the transition, which was of equal gradation throughout, appears much more sudden in transverse sections through the middle region than in those through the base or apex, where the surface is cut obliquely. This may perhaps be true also of the similar observations of Scott and Maslen ${ }^{3}$ for T. Parkinsoni.

Very frequently cells comprising the innermost layer of the sarcotesta are seen cut longitudinally, also in tangential sections (P1. IV, Fig. 5, st.c.) these cells alter their direction in a similar sinuous manner to those of the outer sclerotesta. Here and there slight thickening of the walls can be detected, and the intercellular spaces are either very minute or completely absent. It is clear, then, that the structure of the cells and architecture of the innermost tissue of the sarcotesta were essentially the same as in the outer layers of the sclerotesta-a continuity of structure which can only be reconciled with a homogeneity of origin. As we pass further outwards the intercellular spaces become more and more pronounced, and the constituent cells, at first tubular, very quickly become more rounded, and pari passu, as we pass to the exterior, develop irregularities in the form of projections which connect on to those of adjacent cells and give an almost stellate structure to the tissue (Text-fig. 6).

Owing to the rounded character of the middle sarcotestal cells, the intercellular spaces between them were of more or less equal dimensions in every direction. At a very little distance out, however, the cells were slightly flattened, and tend, especially at the periphery, to form short vertical series separated from one another by elongated lacunae. Sections in this plane also show that the arms or projections of successive cells were often superposed, so that each large lacuna is frequently without trabeculae,

1 On the Fructification of $N$. heterophylla. Proc. Roy. Soc. London, vol. cxcvii, 1904, p. I.

: Archives néerlandaises d. sci. exactes et naturelles, sér. iii, B, tome i, 1911, p. 25.

- Ann. Bot., vol. xxi, No. lxxxi, 1907 . 
and the projections themselves often appear as narrow vertical series partially or completely separating adjacent intercellular spaces (Pl. IV, Fig. Io). Although the above fundamentally expresses the arrangement of the cells in this region, it was subject to great irregularity.

In the living condition this tissue must therefore have been remarkably light and spongy, and if these seeds were shed into water would render them of great buoyancy. Several seeds of this affinity, e.g. Trigonocarpus Parkinsoni, ${ }^{1}$ Pachytesta, ${ }^{2}$ and Aethiotesta elliptica, ${ }^{3}$ exhibit a lacunar sarcotesta, and the suggestion put forward by Renault for Acthiotesta that this served as a mechanism for dispersal by water may well have been true also in the present instance, all the more that the method of occurrence of

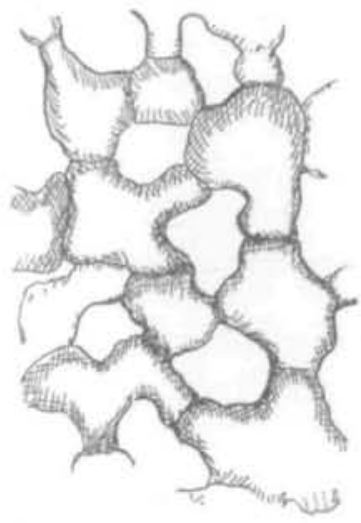

TkxT-pIg.6. A small portion of the outer sarcotesta, showing the large intercellular spaces. fossilized vegetable remains favours the view that they were in part components of water-borne drift.

(b) The Peripheral Zone. At the exterior the sarcotesta was bounded by a very ill-preserved layer of thin-walled cells $(x \cdot 5 \mu-3 \mu$ tangential $\times 2 \mu$ radial). Beneath this epidermis there were numerous sclerized fibres between which a softwalled parenchymatous tissue was most likely present originally, though all except a few remnants of walls have become disintegrated.

The total width of this peripheral zone where there is no evidence of crushing or contraction is about $0.3 \mathrm{~mm}$. In most cases the sclerized elements appear irregularly scattered, probably due to post-mortem changes, as in several places,

where this zone has almost retained what was probably its original width, they are seen to be grouped together to form somewhat irregular radial plates (PI. V, Fig. 19). Each plate was formed of from 2 to 6 elements, the higher number probably being the more usual, whilst tangentially the groups generally form either a single or a double row.

Not infrequently there were considerable local aggregations tangential to the surface, forming broad bands which may well have arisen through the lateral fusion of a number of the sclerotic plates. In outline each broad band formed a continuous hypodermal layer of sclerotic elements, with occasional projections inwards. Owing to crushing and contraction, many of the sclerotic bands have come to occupy an oblique or even tangential direction, causing irregularity and superposition of the originally radial plates

1 Scott and Maslin, loc. cit., p. ror.

2 Renault : Bassin houiller et permien d'Autun et d'Épinac, vol. iv, p. 390, and Pl. LXXXIII, Fig. 10.

3enault: Mém. Soc. d. Sci. nat. d. Sabne-et-Loire, p. 1, 1887. 
The individual sclerotic fibres were roughly rectangular, with a slight flattening in the radial direction, and usually about $2.5 \times 4.5 \mu$. The wall was much thickened (about $0.8 \mu$ ) and formed of an outer transparent, yellowish layer and an-inner and slightly thicker brown layer, both of which show clearly defined lamellation.

The longitudinal sections do not show the outer region of the sarcotesta preserved. The maximum longitudinal dimension in oblique sections is a quarter of a millimetre, and no doubt the real length was much greater.

The width of the intervals between successive plates is usually fairly regular, but rarely they are seen in very close proximity even where there is no evidence of displacement, and these are, perhaps, like the larger aggregations, to be interpreted as due to anastomoses.

Irregularly interspersed amongst the sclerotic cells are numerous secretory sacs, some $7.5 \mu$ in diameter, which were no doubt situated in the soft parenchyma between the sclerotic plates, and become very numerous just beneath this zone.

Here and there the secretory sacs occur two or three together, arranged radially, and it is possible that these too, as in the nucellus, formed rows alternating with those of the sclerized elements.

Where cut obliquely, the secretory cells show fine longitudinal striation of the external surface of their walls; in one section, which is especially well preserved, this wall is seen cut transversely as a series of dark beads separated by clear spaces of about equal width. Surrounding the carbonized contents is a clear space which probably represents a thick sclerotic wall: the elements, in fact, were almost identical in appearance with the thickwalled mucilage sacs found in the sporophylls and testa of present-day Cycads.

In favourable cases, four or five connexions at more or less regular intervals can be seen between the dark central mass and the thin external wall. They probably represent radial pittings of the cell-wall, but must not be confused with the numerous and much finer and fainter radial striations, which are doubtless a matrix effect.

Occasionally the secretory sacs were situated at one or other end of the sclerotic plates, or even in the middle, replacing the sclerotic elements themselves. ${ }^{1}$

The presence of the numerous hard plates in the peripheral zone of the sarcotesta must have given to that region considerable rigidity, and the dark layer often seen between it and the soft underlying tissue is no doubt to be interpreted as originating through the compression of the outer cells of this latter.

(c) The Secretory System. The sarcotesta is not only distinguished from that of other seeds by its extreme development, but also by the

1 Cf. Petiole of Medullosa. Scott's Studies in Fossil Botany, Fig. 176. 
numerous secretory sacs which permeate it throughout (PI. IV, Fig. 2, m.s.). In all respects the secretory elements of the interior appear to agree with those of the periphery.

Each secretory sac is sheathed by a continuous layer of parenchymatous cells, which separate it off from the surrounding lacunar tissue. Component cells of this sheath are seen in tangential sections to have been vertically elongated and to have reached a length of some five times their width.

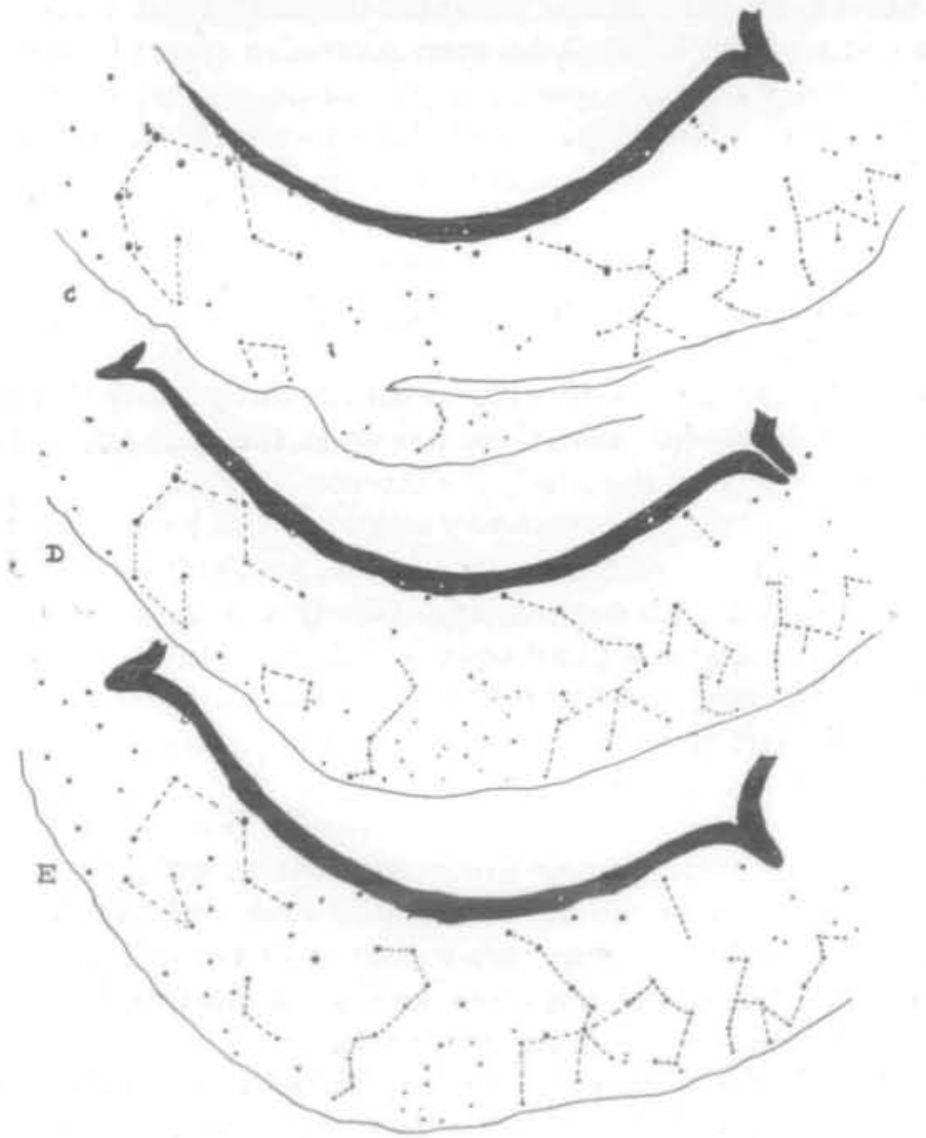

TEXT-FiG. 7. Plottings of the secretory secs in three successive sections. In order to make the corresponding sacs more clear, they have been connected up by means of dotted lines.

By carefully mapping the distribution of the secretory sacs between the same pair of ribs in successive sections of a series, one can recognize, from the relative positions which they occupy to one another, that the same sacs often extend for a considerable distance (Text-fig. 7).

In the subjoined table an analysis of the results obtained from $\mathrm{S} .{ }_{3} \mathrm{I}$, $b-i$, is given; the vertical series show the number of sacs in each section which can be traced back as far as that of which the designating letter 
heads the column. In Section $f$ the sarcotesta is much broken, hence the figure for $g$ is probably double its real value. If this be the case, then the number of additional sacs appearing at any given level is about twenty-one, or sixty-three for the whole circumference. The whole interval included between S. $3 \mathrm{I}, b$ and S. $3 \mathrm{I}, i$ is about $\mathrm{I} 4 \mathrm{~mm}$., and out of the total of 195 separate secretory elements encountered, not more than eight persist throughout. A few are only present in one section, whilst the greater number extend into the next (an interval between sections of about $2 \mathrm{~mm}$.) with a falling off in each successive section:

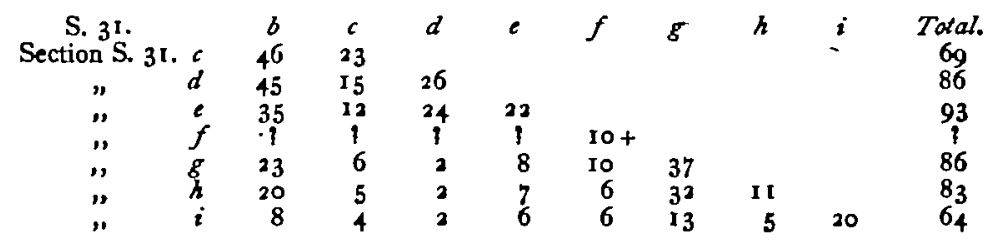

The level of $k$ in the Manchester series is the base of the micropyle, and of $c$ that at which the nucellus is attached to the chalazal cushion. The number of secretory sacs in each case represents approximately onethird of the total at that level.
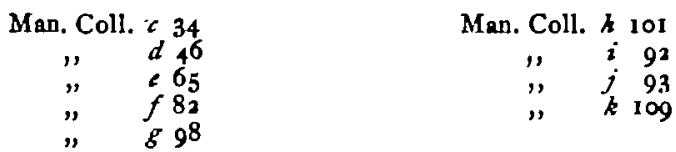

A study of the two series shows that, in spite of irregularities, there was a decrease in number both towards the apex and base. From a comparison of the same sacs cut at different levels, they are seen to have tapered gradually both above and below, so that where cut across near their terminations they are of very small size and, where the surrounding wall is disclosed, very closely resemble developmental stages in the formation of secretory canals, the surrounding sheath simulating an epithelium, which may perhaps be the explanation of the similar appearances described by Professor Seward in the medullosean petiole Rachiopteris Williamsoni. ${ }^{1}$

A single secretory element, as seen in one section, is in several instances replaced by two in intimate contact in the succeeding section (PI. V, Fig. I2); the fact that both are usually of nearly the same cross-section seems to favour the view that this is due to branching.

The hormal course followed by the secretory elements was slightly sinuous and approximately parallel to the direction of the surface, with an outward tendency exhibited by the more interior. The distribution was irregular, with a marked increase-especially of the smaller-towards the periphery; whilst the largest $(0.124-0.166 \mathrm{~mm}$.) are found midway between the sclerotesta and the external surface (cf. Text-fig. 3, p. 42).

1 Ann. Bot., vol. viii, No. xxx, 1894 - 
3. The Inner Flesh.

All those sections which pass through the body of the seed, even where the preservation of soft tissues is excellent, show no indications of an inner flesh. It is certainly true that in most of the preparations the internal surface of the sclerotesta exhibits an irregular outline, but in the transverse series S. $33, a-\mathrm{S} .33, d$, in which the internal preservation is almost perfect, the inner margin of the sclerotesta in some places forms a perfectly even surface. This latter affords positive evidence of far more value than the negative evidence of a ragged surface, and still more so since we find in the badly preserved material that the sclerotesta does show signs of superficial disintegration.

In dealing with the nucellus we shall find that it was possessed of a highly differentiated and probably strongly cuticularized epidermis, and there is evidence that it was in close contact with the sclerotic tissue.

Having due regard to all these facts, one is forced to the conclusion that in this species of Trigonocarpus an inner flesh was not present in the middle part of the seed cavity.

When we come, however, to about the level of the insertion of the micropyle, the zone of sclerization begins as it were to shift slightly outwards, and we thus find within the sclerotesta several layers of cells which, though possessing thick walls, have not the dark brown contents of the sclerotic fibres themselves, and, moreover, become thinner-walled as we pass inwards: This tissue reached its maximum thickness, of some four layers, midway between the angles, and on its inner margin exhibits a broken surface that here might well indicate a greater extent of probably more parenchymatous elements (Pl. IV, Fig. 8, i.f.).

Even then, if we regard this micropylar lining as homologous with the inner flesh of other Trigonocarpeae, our seed is as extreme a member on the one hand, as Pachytesta on the other.

\section{The Vascular Organization.}

\section{(a) The Chalasal Bundle and Nucellar System.}

The lowest of our transverse sections yields us no information as to the vascular structure, but from S. 33, b, Man.R. I I6I, $b$, and the longitudinal section $S .3^{2}, e$, we find that a single vascular bundle entered the chalazal end of the seed. This passed up to the base of the nucellus, at which level it is cut by the section. S. $33, b(\mathrm{Pl}$. V, Fig. I6). The bundle is there seen to have been a solid mass of xylem very slightly triangular in outline, the angles corresponding in position with the three main ribs of the seed. It was formed of from sixty to seventy elements, and attained a diameter of about $0.18 \mathrm{~mm}$. The larger tracheae are situated mostly at the periphery 
(Pl. V, Fig. 16); and in their radial dimension $(30-40 \mu)$ considerably exceed their width $(75 \mu-0.025 \mathrm{~mm}$., average about $0.015 \mathrm{~mm}$.). The central elements are polygonal in form and from $0.015 \mathrm{~mm}$. to $0.02 \mathrm{~mm}$. in diameter. The bundle therefore has the appearance in transverse section of a central core surrounded by a single layer of radially flattened elements.

The smallest tracheae, measuring some $0.8 \mu$ in diameter, lie just within this outer layer and appear to form six not very clearly defined groups, two corresponding to each of the three angles. That these are the protoxylem elements is rendered the more probable by an examination of the single longitudinal section passing through the chalazal bundle (S. 32,e). From this we find that the majority of the elements were scalariform or densely spiral (Pl. V, Fig. I8), whilst separated by one such element from the periphery of the bundle there appear to be one or two narrow elements with distant spiral thickenings.

The xylem is completely surrounded by a ring of parenchymatous tissue (Pl. V, Fig. 16, p.s.) composed of three to five layers of thin-walled elements which together attain a width of about $0.05 \mathrm{~mm}$. In the longitudinal section this tissue is seen to have consisted of narrow, vertically elongated components, perhaps undifferentiated phloem. The whole bundle, including this delicate sheath, was surrounded by larger-celled and thinwalled nucellar tissue in which were numerous secretory sacs. One element exhibits parallel markings, and may be a transfusion tracheide comparable perhaps to those found by Scott and Maslen between the bundles of the sarcotesta of T. Parkinsoni (loc. cit., p. II 4 and PI. XIV, Fig. 25, st.).

The single bundle passed through the base of the nucellus, where it expanded in a cup-like manner and formed a tracheal investment ( $\mathrm{I}-4$ elements) to the megaspore cavity. This is well seen in section $\mathrm{D}$ of Dr. Scott's series, which passes obliquely through the base of the megaspore cavity, and shows the continuous and several-layered tracheal cup around its base.

As seen in transverse section, the tracheal mantle appears to be built up of broad, laterally fused, bands traversing the longitudinal direction which are thickest in the middle and gradually diminish towards the sides. As can be seen from the plottings (Fig. I), the section S. 33, $C$ is slightly oblique to the axis of the seed, and it is on the higher side of the section. that this grouping of the tracheides is the more marked.

Presumably, then, the vascular tissue between the level of this section and the base of the megaspore cavity consisted of a uniform zone of tracheides, which on the upper side became incompletely segregated into. bands. The number of these latter cannot be ascertained with certainty, owing to the oblique direction of our most nearly transverse sections, but if we assume the slight indications of thinning on the lower side to mark the lateral limits of vascular aggregations, then there were probably twelve such 
bands, the width of the more clearly delimited varying between $1 \mathrm{~mm}$. and $\mathrm{r} \cdot 3 \mathrm{~mm}$.

The internal diameter of the megaspore cavity, as seen in section S. 33, c, from which the above data were obtained, is $4.4 \mathrm{~mm}$., which represents a periphery of approximately $13.8 \mathrm{~mm}$. If we assume each band to have been of equal width, this gives us $1.15 \mathrm{~mm}$. as the measurement of each if their number were twelve. This figure is sufficiently close to the actual measurements to support the belief that this was the actual total of the bands. Unfortunately, none of our other preparations furnish any corroborative data, but it is worthy of note that the repeated hexamerous character of the seed-structure again recurs in this figure.

The next section (S. 33, d), though ill preserved, shows the tracheides were completely segregated into lenticular strands which were much narrower $(0.25 \mathrm{~mm} .-0.5 \mathrm{~mm}$.) and more numerous than at the preceding level (probably over twenty).

These strands were probably mesarch in structure, of from four to five elements in the radial plane, diminishing both in number and size on either side. In some cases, tracheides at the edge of the xylem bands can be seen passing horizontally, as is the case in Trigonocarpus Parkinsoni, ${ }^{1}$ but actual connexions were not observed.

Tangential sections show that the individual tracheides were often oblique or curved, and the appearance of horizontally directed elements, in the slightly oblique transverse sections, might easily be accounted for in this way. In spite of the excellent preservation, no indication of phloem has been observed in relation to the nucellar strands.

The final section of the transverse series only contributes confirmatory evidence that the bands of xylem were disconnected, and that their smallest elements were centrally placed.

For the further course of the bundles only longitudinal and oblique sections are available. In these, the bands of tracheides can be traced to what must have been a level close to the floor of the pollen chamber. Only two sections, viz. S. $3^{2, c} c$ and Section I of Dr. Scott's series, actually pass through this structure; neither of these shows any tracheides within, but the internal preservation of the latter section is very poor, whilst the former has a broken and ill-preserved floor.

The vascular elements of the nucellar system appear to be very uniform in structure $(0.022-0.03 \mathrm{~mm}$.), and exhibit scalariform thickenings which occasionally show anastomoses between adjacent horizontal bars. (Interval between bars, $0.0015-0.003 \mathrm{~mm}$.)

From the above description it will be seen that the internal vascular system is almost identical with that described by Scott and Maslen for Trigonocarpus Parkinsoni (loc. cit., pp. 120-1), and it may be of some

1 Scott and Maslen, loc. cit., Pl. XIV, Fig. I 3. 
significance that in neither species has the nucellar system been traced beyond the plane of insertion of the pollen chamber.

\section{(b) The Sarcotestal System.}

In several sections of the University College series S. $3 \mathrm{I} a-\mathrm{S} .3^{\mathrm{I}}, k$, and perhaps in section R. II6I, $h$ of the Manchester series, bundles in various conditions of preservation are to be found at the extreme periphery of the sarcotesta proper, where the outermost lacunar tissue abuts upon the limiting layers containing the radial sclerotic plates. The only parallel amongst nearly allied seeds to so external a position is to be found in Pachytesta, ${ }^{1}$ where, however, if we regard the exotesta as representing sarcotesta and sclerotesta combined, ${ }^{2}$ the bundles are only far out if considered in relation to the testa as a whole.

Owing to the incomplete preservation of the periphery, it is hardly surprising that in no slide are more than three sarcotestal bundles present at one and the same time. In several of the University College series, S. 31, $a-$ S. $3 \mathrm{I}, k$, two bundles are cut in successive sections, and both of these are fortunately situated between the same pair of major ribs, and also occupy the same positions relative to them. Altogether, four distinct bundles can be distinguished in this series, and two possible bundles are also recognizable in one of the Manchester sections (R. II6I, $h$ ). In every case these sarcotestal vascular strands are situated in the radial plane midway between a major and a minor rib; and though the bundles are not present, in any one of our specimens, on all three faces, yet the occurrence of two, and two only, in several successive sections between the one pair of major ribs seems to point conclusively to the total number as being six, symmetrically disposed around the circumference of the seed.

The sarcotestal system was then identical as to the number of its components, and almost so as to their arrangement, with that which has been described for Trigonocarpus Parkinsoni and Polylophospermum, ${ }^{8}$ only differing in the latter respect with regard to the proximity of the bundles to the sclerotic shell,

The structure of an individual strand is shown in S. $31, i(\mathrm{Pl}$. V, Fig. I7), where, owing to the curvature of the surface, the section which is oblique to the axis of the seed passes transversely through a sarcotestal bundle exhibiting extraordinarily perfect preservation. As can be seen from the figure, the bundle is slightly more extended in the tangential than in the radial direction $(0.29 \mathrm{~mm} . \times 0.17 \mathrm{~mm}$.) and consists of some seventy xylem elements, of which the smallest occupy the central region (PI. V, Fig. I7, pt. $x$ ). The latter, which probably represent the protoxylem, comprise some

1 Renaalt, loc. cit.

2 Oliver : On Gymnospermons Seed, New Phytologist, vol. i, No. 7, 1902, p. 148.

- Oliver, Ann. Bot., vol. xxi, No. lxxxii, I907, Pp. 303-4. 
four tracheides $(0.0075 \mathrm{~mm} . \times$ from $0.0075 \mathrm{~mm} .-0.015 \mathrm{~mm}$.) with thicker walls than those around. From the mesarch protoxylem there extends in the centrifugal direction an irregular fan-shaped group (PI. V, Fig. I 7, cf.x.), the elements of which, though larger than those of the protoxylem, are distinctly smaller than both those which lie on their flanks and those on the inner side of the bundle.

The centripetal xylem (P1. V, Fig. 17, cp.x.) exhibits a further distinction in that the elements here are mostly cut more or less obliquely, so that the scalariform or reticulate sculpturing of their walls can be seen. A single layer of xylem elements on the centripetal side of the bundle immediately next the protoxylem do not show this character, although they. exhibit the increased dimension.

The bulk of the centripetal wood evidently then consisted of short tracheides, such as are frequently present in centripetal xylem that is becoming obsolete, as is exemplified in Lepidodendron vasculare ${ }^{1}$ or Osmundites Kolbei. ${ }^{2}$

\section{(c) Additional Facts as to the Vascular System of Trigonocarpus Parkinsoni.}

The course of the sarcotestal bundles at the base of the seed of Trigonocarpus Shorensis cannot be traced, as the peripheral portion is lacking in the sections which pass through that region.

Two sections probably belonging to Trigonocarpus Parkinsoni, viz. S. 34, $a$ and S. 34, $b$ of the University College collection, have however recently come to hand, which Prof. Oliver has also placed at my disposal for description, and which, owing to their excellent preservation, add considerably to our knowledge of the vascular structure in this region. The absence of similar data regarding our own seed, and the essential similarity between the vascular systems of the two species, are sufficient justification for inclusion here.

The first section, viz. S. 34, $a$, just passes through the lower limit of the sclerotesta, and the second, parallel to the first, obliquely through the seed base, but without traversing the megaspore cavity. In this latter section eight ribs can be distinguished, of which three are doubtless the primary ribs, and from-the distribution of the remaining five it seems likely that the seed was twelve-angled, the missing ribs having become obliterated either by obliquity or in consequence of the lower level at which the seed is cut on one side. A further point of importance is that this seed was evidently blunt at the base and not tapering,

1 Hovelacque, M. : Recherchés sur le Leputöderutron selaginoides, Sternb. Mém. Soc. Linn. Normandie, vol. xvii.

2 Kidston and Grynne-Vaughan : On the Fossil Osmundaceae, Pt. IV. Trans. Roy. Soc. Edinbargh, I gro. 
as shown by the great difference in the area of sclerotesta sectioned at, the two successive levels. These facts, taken together with the position of the sarcotestal bundles, seem to justify the assumption that the seed was Trigonocarpus Parkinsoni.

In both of the sections a few secretory sacs can be seen. Dr. Scott has. permitted me to examine his best preparations of T. Parkinsoni with the sarcotesta preserved, and particularly Wild's section S. 1952, figured by Scott and Maslen, ${ }^{1}$ in which there are present some dark bodies surrounded by a clear space $0.045 \mathrm{~mm} .-0.05^{2} \mathrm{~mm}$, in diameter. Neither for these nor for similar bodies in the other preparations can one definitely assign a secretory. nature, but a comparison with ill-preserved secretory sacs of $T$. Shorensis discloses a striking similarity between them. Probably, then, secretory sacs. were present in T. Parkinsoni, both at the base and apex of the sarcotesta, but in very much smaller numbers than in $T$. Shorensis.

The central region of the lowest of the two sections cuts the single main chalazal bundle obliquely, at the level where the sclerotesta begins to be differentiated.

The general outline of the vascular bundle was very slightly triangular, with a diameter of about $0.3 \mathrm{~mm}$., the angles corresponding in position to the secondary ribs. From each of the two upper of these angles (Pl. V, Fig. $14, v . b$.) a strand is seen in process of being given off into the sarcotesta.

The main bundle is surrounded by a thin-walled parenchymatous tissue (par.) consisting of vertically elongated elements. In the centre is a solid mass of xylem, throughout which are scattered short tracheides horizontally directed, exhibiting scalariform or pitted thickenings. The section is sufficiently oblique to show that the longitudinally directed tracheides were scalariform.

In the centre of the xylem a single secretory cell can be detected. (Pl. V, Fig. 14, m.s.).

The periphery of the bundle is formed of a band of short tracheides I-2 elements in width, which for the most part are separated from the central xylem mass by what appears to have been parenchymatous tissue similar to that surrounding the bundle as a whole. But this tissue is interrupted at several points by junctions between the outer and inner tracheides. The smallest xylem elements lie mostly at the periphery of the central core, but others are situated more interiorly.

From an examination of the angle which is cut at the highest level, it can be seen that from this peripheral zone pass out the xylem elements of the sarcotestal bundles. In this particular case, the portion has partially separated off from the central mass, and the corresponding bundle, owing to the double obliquity of the section, is again cut further

1 Loc. cit., Pl. XII, Fig. 1 I. 
out in the sarcotesta. What was doubtless the second half of this strand is seen at the edge of the bundle cavity, and clearly shows that the course of the two halves was divergent.

In the next section, viz. S. $34, b$, which is nearly parallel to the former, five sarcotestal bundles can be distinctly recognized, whilst the position of a sixth is marked by a lacuna.

Where the bundles are cut on the lower side of this section, the level is only about one-third of a millimetre above that at which the central bundle is cut in the previous slide, so that the distance is scarcely sufficient for other bundles to have been given off.

It would appear then, from these two preparations, that three bands of xylem in continuity with the peripheral part of the chalazal strand were given off simultaneously, each of which then almost immediately underwent bifurcation into two divergent halves.

The soft parenchymatous tissue which surrounded the bundle consisted of cells which, when cut transversely, appear more or less polygonal and isodiametric : where cut longitudinally they measure about $0.12 \mathrm{~mm} \times 0.022$ $\mathrm{mm}$., and are separated by slightly oblique transverse walls. This tissue may perhaps have served the purpose of phloem, though apparently quite undifferentiated; that it had some definite function is supported by its sharp delimitation from the surrounding tissue, even where this too was parenchymatous in nature. A similar sheath accompanied each of the six sarcotestal strands in this, the basal region of the seed.

As seen in S. 34, $b$ (Pl. V, Fig. I5) the central part of each bundle was occupied by a strand of elongated scalariform tracheides (n.tr.), and around this was a complete ring of much shorter and stouter spiral or slightly reticulate elements (s.tr.). Separating the outer zone from the central core, was a narrow space from which the bulk of the tissue has perished, but here and there can be seen patches of elongated parenchymatous elements similar to those forming the bundle-sheath, and no doubt they originally constituted a complete ring.

Each sarcotestal bundle was then essentially similar to that supplying the chalaza. An examination of the bundles of Dr. Scott's section 626 of $T$. Parkinsoni through the same region as S. $34, b$, though exhibiting far less perfect preservation, seems to agree with the description here given.

Before leaving these sections it should be said that, though the type of preservation is the same as that of the bulk of the specimens of $T$. Shorensis, in none of the secretory elements present was I able to find the longitudinal striation characteristic of the wall in that species, though this feature is exhibited by well-preserved ducts in the stems of Medullosa anglica. 


\section{The Nucellus.}

The total length of the free nucellus, from the point of junction with the testa to the base of the pollen chamber, was about $18 \mathrm{~mm}$., and its diameter in the widest region about $I \mathrm{Imm}$. As the cavity in this part was some $15 \mathrm{~mm}$. in width, there is left a space of $2 \mathrm{~mm}$. all round for which to account. The question of an inner flesh has already been discussed, but in any case these dimensions for the nucellus are probably much too small, owing to post-mortem contraction.

The general outline of the nucellus conformed closely to that of the cavity within which it stood, following the same lines until near the base of the micropyle, where the nucellar tissue curved sharply inwards to the insertion of the pollen chamber.

Disregarding this latter structure, the conformation was that of a sharply pointed egg with its narrower end directed downwards and attached to the sclerotesta, whilst the blunt free end was surmounted by the pollen chamber.

The nucellar tissue is in most cases either lacking altogether or ill preserved, but fortunately, in the transverse series S. 33, $a$ to S. 33, $d$, the structure is beautifully shown, though considerably contracted. In the uppermost of the series the nucellus occupies a one-sided position which is in part due to the slight obliquity, but no doubt in the main to displacement through asymmetrical shrinkage.

In the second of this series the nucellar tissue is seen surrounding the chalazal bundle. As already described, this consists of parenchymatous tissue, of which the cells are thin-walled and vary in size from about 0.01 to $0.050 \mathrm{~mm}$., interspersed with secretory ducts, the largest of which are at the periphery and measure about $0.07 \mathrm{~mm}$. in diameter. This ring of tissue is only $0.2 \mathrm{~mm}$. in width, but from its ragged edge was evidently much more extensive in life.

Owing to the shrinkage of the soft underlying tissue, the much less contractable epidermis is thrown into numerous folds, but the projections thus formed do not, as in Trigonocarpus Parkinsoni, correspond to underlying vascular strands, ${ }^{1}$ but to radial files of secretory elements (Pl. V, Fig. 20, m.s. and n.r.). Taking the distance from the edge of the megaspore cavity to the summit of these ridges as the basis of our estimate, the thickness of the nucellar tissue must have been, near the chalazal end of the seed, at least $0.3 \mathrm{~mm}$., though above this level it diminished slightly and then remained of constant width up to the base of the pollen chamber. At the outside there was a very strongly defined epidermis, (S. 33, c, Pl. V, Fig. 2c, 1.e.), the cells of which $(0.05 \mathrm{~mm}$. radial $\times 0.03 \mathrm{~mm}$. tangential) stand out all the more clearly since their contents are preserved as dark carbonaceous masses that have contracted away from the cell walls. Where, owing to the contortions

\footnotetext{
1 Scott and Maslen, loc, cit., p. I 19.
} 
of the surface, the longitudinal dimension can be estimated, it is about three times as great as the width $(0.09 \mathrm{~mm}$.). As seen in this view, the cells are more or less oblong in shape, whilst cut transversely they appear distinctly convex on the external face, a feature which seems to point to the absence of close contact with an inner flesh.

Under the best conditions of preservation, the epidermal cells resemble very closely the secretory. sacs and, like them, have the appearance of possessing a thickened wall. In several places the outer layer of the exterior walls, together with part of the middle lamellae from between each pair of the component cells, has split away, so that in transverse section it appears as a thin membrane with pegs projecting inwards. Evidently this outer layer was of a durable character, as it can occasionally be recognized even where the interior tissue has decayed away, and is much less subject to contraction, suggesting that it may probably have been a cuticularized layer such as we find with similar pegs amongst modern plants.

Such a specialized epidermis we should hardly expect to find in a. completely enclosed structure like the nucellus, if it were in close contact with a soft inner flesh.

Between the epidermis and the tracheal sheath there intervened a zone of soft parenchymatous elements in which numerous secretory cells were present. . The ground-tissue was without intercellular spaces and formed of polygonal cells with very thin walls $(0.03 \mathrm{~mm}$. to $0.08 \mathrm{~mm} . \times 0.15 \mathrm{~mm}$.), The secretory cells were embedded in this ground-tissue, and where they did not occur singly, formed radial plates of varying extent and usually consisting of a single row of secretory elements, though more rarely at the base of the seed of two such rows. The greatest number of secretory cells which were present in any one radial plane appears to have been five. The proximity of the radial plates and the number of elements in each decreased as the apex of the seed was approached, so that some two-thirds from the base of the pollen chamber the plates were about a third of a millimetre apart and reduced to one, two, or at the most three elements. The secretory sacs themselves $(0.06-0.09 \mathrm{~mm}$.) exhibit much the same structure as those of the sarcotesta, but with thinner walls. In the longitudinal direction the carbonized contents show segmentation into short lengths, but the septation thus produced probably bore no relation to transverse walls.

In two of the seeds (viz. S. 3 I, U. C. Coll., and Man. R. II6I), besides the longitudinal ridges already referred to, others more pronounced are present, occupying positions opposite to the commissural ribs, and bear no relation to contained radial files of secretory elements. In the series S. 33, U. C. Coll., with its excellently preserved nucellus, no such ridges are however to be seen, which may be correlated with the fact that this seed was probably in an immature condition, judging from its relatively small size, the thinness of the testa, and the slight development of the ribs. In S. $3^{1}, g$, 
such ridges, corresponding to both the major ribs preserved, can be distinguished. Such commissural ridges, ${ }^{1}$ of which an example is figured in Pl. V, Fig. . 3 3, n.f., from section S. 3I, e, furnish the strongest evidence that the nucellar surface was in the mature condition in close contact with the sclerotic testa, a point which the well-developed cuticle further emphasizes.

\section{Vi. The Pollen Chamber.}

Our information respecting the structure of the pollen chamber is extremely meagre, as only two sections furnish data of any importance. The general form of the pollen chamber, as seen in S. $3^{2}, c$, is rectangular, with longer sides forming the roof and floor ( $3 \mathrm{~mm}$. wide $\times \mathrm{I} .26 \mathrm{~mm}$. high). As will be seen from the diagram, the direction of the section passes tangentially through the pollen chamber in a plane slightly oblique to that of a minor rib.

The central part of the roof in this section shows a triangular, bluntended, upward projection of the epidermis, which may be the base of the micropylar tube.

The epidermis of the pollen chamber is continuous with that of the nucellus, and the component cells up to about half its height are of the same form in both. Beyond this point they become much larger $(0.066 \mathrm{~mm}$. radial by 0.04 to $0.08 \mathrm{~mm}$. vertical), with thinner walls, and do not possess the black carbonaceous contents present in the lower part. The increased size is especially noticeable where the sides curve inwards to form the roof ; these shoulders project somewhat laterally, partly owing to the larger size of the epidermal cells and partly to the slightly greater internal diameter $(\mathrm{Pl} . \mathrm{V}$, Fig. 1I). The blunt apex of the angular projection is formed of cells which are much narrower in the tangential direction, $0.005 \mathrm{~mm}$. Interiorly, the sides of the pollen chamber were occupied by a soft parenchymatous tissue, consisting of elongated cells with tapering ends. This is most pronounced in the shoulders, and the appearance presented very closely resembles that described and figured for other seeds of this affinity, as for example T. Parkinsoni, ${ }^{2}$ T. pusillus, ${ }^{3}$ Aethiotesta, ${ }^{4}$ and Stephanospermum. ${ }^{5}$

In S. $32, h$, the pollen chamber exhibits a prominent angle corresponding in position to a major rib, and also in Section I of Dr. Scott's series the shoulders appear double-angled, the lower of the four angles being the true

1 Cf. Renault: Angling of Nucellus in Trigonocarpus pusillus. Flore fossile d'Autan et d'Épinac, pt. 2, p. 398.

2 Scott and Maslen, loc. cit., p. I 2 I.

Oliver: New Phyt., vol. iii, I904, Pl. II, Fig. 3.

4 Renault : Mćm. Soc. d. Sci. Nat. de SaÔne-et-Lolre, 1887, Pl. XVI, Fig. 3.

- Oliver: Trans. Roy. Soc. Lond,, p. 370, Pl. XLII, Figs. 1 I and I8. 
shoulders, and the upper again coinciding with the positions of major ribs. There seems little doubt, then, that the pollen chamber was three-angled in correspondence with the projections of the nucellus lower down.

\section{COMPaRISON WITH OTHER TyPES.}

J. Trigonocarpus Parkinsoni, Brongniart.

It is hardly necessary to recapitulate in detail the many points of general resemblance which Trigonocarpus Parkinsoni and Trigonocarpus Shorensis have in common. The main structural plan in both seeds is essentially the same, but this only serves to throw into greater prominence the many differences of their more minute structure.

We note the entire absence in Trigonocarpus Shorensis of tertiary ribs subtending the vascular bundles, and though the behaviour of the primary sutured ribs is alike in each, the beak into which they pass is short in T. Shorensis and long in T. Parkinsoni.

The secondary ribs of the latter seed are subject to considerable variation, sometimes being almost absent; but usually they persist to near the apex, where they die out before the micropylar beak is reached, an earlier disappearance of the secondary ridges which is still more pronounced in T. Shorensis. Scott and Maslen give the thickness of the stony layer in T. Parkinsoni as from $\mathrm{I}$ to $1.5 \mathrm{~mm}$. (loc. cit, p. 106), which is two to three times the corresponding dimension for our seed. Probably this added thickness and the increased number of ribs are to be correlated with the small extent of the sarcotesta, as compared with that of $T$. Shorensis, necessitating greater mechanical strength in the layer beneath; or perhaps, put more correctly, the broad sarcotesta in the latter species, with its peripheral sclerotic system, had not involved the necessity for development of such mechanical strength in the sclerotesta.

The most interesting comparison between these two seeds is afforded by the sarcotestal structure. This tissue was in T. Parkinsoni bordered at the exterior by a narrow epidermis, followed by a thickened palisade-like hypodermis (Scott and Maslen, loc. cit., p. 102). As we have seen, the limiting layers in the present seed were much more complex, and formed a, probably anastomosing, complex of radial plates, accompanied by numerous secretory elements present also further in, which, though represented, were extremely few in T. Parkinsoni. Now the occurrence of radial sclerotic plates at the periphery, and of secretory elements both within these and interiorly, are characteristic features of the vegetative organs of Medulloseae, and especially of their petiolar structure, ${ }^{1}$ so that $T$. Shorensis in this respect would appear to be far more primitive than its congener. The absence of the prolonged

1 Scott, D. H.: On Medullosa anglica. Phil. Trans., B, vol. cxci, p. ror, and Pl. VIII, Fig. 18, 1899 . 
sclerotic beak and secondary ridges opposite the bundles also point to a lesser degree of specialization.

A further striking difference is the tapering insertion of the seed of $T$. Shorensis as compared with its abrupt insertion in T. Parkinsoni; the former is probably a relatively older type than the latter, just as the horizontal departure of the leaf-trace characterizes the modern plant, in contradistinction to the oblique insertion, as found in the more ancient.

Analogy with Physostoma elegans ${ }^{1}$ would seem to suggest that the presence of a secretory system in the nucellar tissue is a more prinitive feature than its absence. If this has any significance, and the close relationship between the Trigonocarpeae and Lagenostomales supports such an assumption, then in this respect $T$. Shorensis stands in the same relation to T. Parkinsoni as does Physostoma to the other known members of the latter group.

We have shown good reason for believing that $T$. Shorensis was without a definite inner flesh, except in so far as we can apply that term to. the lining of the micropylar canal. Such a tissue would, however, appear to have been present in T. Parkinsoni. Perhaps at first sight this might seem to be a pronounced distinction between the two, but the extreme peripheral situation of the sclerized layer in Packytesta, surrounding an extensive inner flesh, coupled with the undoubtedly close relationship of the two genera, indicate that the position taken up by the region of sclerization was subject to considerable fluctuation in the group as a whole, and therefore of no great significance when exhibited in a smaller degree by members of the same genus.

The well-defined nucellar epidermis, even more pronounced than that of T. Parkinsoni, indicates a stage less far removed from the condition in which the nucellus was a naked sporangium unprotected by a surrounding integument; and probably the production of an inner flesh is likewise correlated with a phylogenetically more prolonged contact between the two surfaces, which functionally have become internal.

As previously indicated, the vascular organization of the two seeds was essentially similar, perhaps the most outstanding distinction between them being the much more peripheral position occupied by the sarcotestal strands in Trigonocarpus Shorensis. On the whole, the internal vascular system of our seed probably shows a somewhat more pronounced tracheal investment at the base of the nucellus, whilst the separate strands into which this passed were broader, though this may well be an outcome of the larger nucellus they supplied. If, as may have been the case, the Trigonocarpeae were derived from fern-like plants having sporangia with a complete internal tracheal investment, then it would appear from Scott and Maslen's description that in this respect Trigonocarpus Parkinsoni was more primitive than

1 Oliver: Ann. Bot., rol. xxiii, p. 73. 
$T$. Shorensis, for in the latter anastomoses, if they existed, were probably of infrequent occurrence.

\section{Trigonocarpus Oliveri; its systematic position.}

This seed was described and figured by Scott and Maslen in 1907, from a series of four sections through a single seed, and the diagnosis there given is as follow's :

'Length nearly $2 \mathrm{~cm}$., diameter about $0.9 \mathrm{~cm}$., characteristically coffinshaped in vertical sections. Base flattened. Sclerotesta produced around the base of the seed in the form of a circular ridge enclosing the stalk of the seed. Longitudinal ridges of the sclerotesta acute-angled, not rounded as in Trigonocarpus Parkinsoni.'

The number of longitudinal ridges which the seed bore is not explicitly stated, but, presumably from the description given, was assumed to have been six.

The writer has carefully examined the preparations and employed for their interpretation the methods recently described. ${ }^{2}$ The conclusions arrived at differ essentially from those of Scott and Maslen, who evidently did not fully recognize the marked effects of obliquity in this seed, which are so clearly brought out by the modelling method.

As can be seen, the first section (S. 28, $d)^{3}$ is tangential to the surface of the seed and passes at unequal depths through two ribs, the divergent axes of which, towards the upper part, indicate that the plane was below the middle region, sloping away from the chalaza. The next section (S. 28,c) shows the more deeply cut of these ribs sectioned nearer the axis, and consequently represented by two angular projections, one at the apex and the other at the base. This section cuts the seed so far in that two lateral ribs, one on either side, are also encountered; where these are cut near the apex they appear as angular projections, whilst near the base they exhibit a curious truncated outline, but are unequal in size, owing to the obliquity which was also manifested in the previous section. It is these two lateral ridges at the base which have been interpreted as a circular ridge, though the true character where sectioned near the apex was recognized. In order to explain the peculiar form of the lower projections, the assumption was made that they were incomplete. The objections against such an interpretation furnished by this section alone are, that if a chalazal ring were present, it is highly improbable that the central rib would extend below it and the lateral ribs be in no way represented; whilst this difficulty cannot be overcome, since the interpretation of the median ridge as a part of the stalk is inadmissible, owing to the plane of section.

1 The Structure of the Palacozolc Seeds Trigonocarpss Parkinsoni and Trigonocarpus Oliveri. Ann. Bot., vol. xxi, No. Irxxi, 1907 .

Salisbury: Methods of Palaeobotanical Reconstruction. Ann. Bot., April, 19i3.

Loc. cit., Pl. XIII. 
On the interpretation here put forward no difficulties are involved, since converging ribs cut in a plane at a narrow angle with that which they themselves follow would necessarily acquire in section the square-ended form which they actually present.

In the section just described, one notes that the region of attachment of the nucellus is cut through, so that since in the next preparation the nucellus shows as a complete oval membrane it is clear that this section passes right across the axis of the seed, cutting through a rib on either side almost vertically, and it is the slight angling of the cavity corresponding to these which, as in similar sections of Conostoma oblongum, results in the coffinshaped appearance.

. At the apex of S. $28, b$, we see the three ribs represented in S. 28, $c$, and at the lower end three other ribs sectioned almost transverse to their direction, so that the triangular form is preserved. If, on the other hand, they were really a chalazal ring, a section in this plane should render them convergent, not divergent, and furthermore, their size on that view is incompatible with the projections in the previous section, especially if the latter are to be regarded as incomplete.

$T$. Oliver $i$ was then an eight-angled seed, and, until further specimens are obtained with better-preserved internal tissues, its systematic position, except for inclusion in the vague group of the Radiospermeae, must for the present remain uncertain. The removal of this seed from the genus Trigonocarpus makes it therefore unnecessary to institute any comparison between it and Trigonocarpius Shorensis.

\section{Fructifications of Neuropteris heterophylla and Neuropteris obliqua.}

Attention has already been called to the tapering and the abrupt insertion found within the genus Trigonocarpus, both of which are represented in the fructifications found attached to Neuropteridian foliage. Three specimens of Neuropteris heterophylla have been described by Dr. Kidston with attached seeds, ${ }^{1}$ in which the abrupt insertion of the Parkinsoni type is clearly exhibited. More recently, Kidston and Jongmans ${ }^{2}$ have described fructifications attached to the fronds of Neuropteris obliqua, in which the seed tapers towards its insertion on a bifurcated axis, thus conforming to the second type as represented by $T$. Shorensis. Owing to the incomplete preservation of the latter at the apex, its longitudinal extent cannot be exactly estimated, but nevertheless the comparison of the approximate dimensions of the two types of impressions and petrifactions given below shows that broadly the resemblances of insertion are accompanied by an approximately similar ratio in size.

1 Phil. Trans. Roy. Soc., ger. B, vol. cxcvii, 1904, p. I.

- Archives uéerlandaises d. sci. exactes et nat., sér. iii, $B$, tome i, 19II, p. 25. 


Species.
T. Parkinsoni
N. heterophylla
T. Shorensis
N. obliqua

$$
\begin{array}{r}
\text { Lergth. } \\
4-5 \mathrm{~cm} . \\
3 \mathrm{~cm} . \\
\text { Over } 4 \mathrm{~cm} . \\
\text { About } 6 \mathrm{~cm} .
\end{array}
$$

$$
\begin{aligned}
& \text { Breadth. } \\
& 2 \mathrm{~cm} . \\
& \mathrm{I} \cdot 1-\mathrm{I} \cdot 4 \mathrm{~cm} . \\
& 2.4 \mathrm{~cm} . \\
& 2.25 \mathrm{~cm} .
\end{aligned}
$$

A further feature that the fructifications of $N$. obliqua and 7 : Shorensis have in common is found in the marked striation exhibited by the surface of the former, and attributed by the authors cited above to the presence of a large number of sclerenchymatous strands of tissue near the surface of the seed. These are no doubt identical with the numerous radial sclerotic plates which we have described as a prominent feature in the peripheral layers of the sarcotesta in $T$. Shorensis.

In view of the occurrence of the seeds of $N$.obliqua in pairs on a bifurcated axis, it may be of some significance that in one of our series a portion of a second sced is present, having approximately the same orientation as the more complete specimen close to which it lies.

These considerations render it likely that our seed was itself borne on a plant possessing foliage of the Neuropteris type, and almost certainly belonged to the same subsection of the genus as Kidston and Jongman's specimens.

\section{Trigonocarpus corrugatus.}

Amongst the casts of Trigonocarpean seeds, none approach so closely to Trigonocarpus Shorensis as that described by Renault under the name Trigonocarpus corrugatus. The following is the diagnosis given by that author:

'Graines trigones, dilatées un peu au-dessus du milieu de leur hauteur, longues de 22 millimètres et larges dans la partie renflée de 12 millimètres, marquées de trois côtes saillantes qui vónt jusqu'au sommet de la graine sans produire de point. Entre ces trois cotes on remarque trois plissements en relief qui s'étendent à peu près jusqu'à mi-hauteur.' ${ }^{1}$

From the above we see that the dimensions of the seed, though smaller than those of our own species, bear very nearly the same ratio for the corresponding parts of the sclerotesta.

$\begin{array}{lccc}\text { Species } & \text { Width }(\text { max. } & \text { Length. } & \text { Ratio } \\ T . \text { corrugatus } & 12 \mathrm{~mm} . & 22 \mathrm{~mm} . & 1.83 \\ T . \text { Shorensis } & 15 \mathrm{~mm} . & 28 \mathrm{~mm} . & 1.86\end{array}$

The presence of the three secondary ribs extending for only a part of the total length of the hard shell, though persisting for a greater distance than in $T$. Shorensis, also the absence of a beak (a description that might easily in this type of preservation be consistent with the presence of a very short structure of such a character), and the tapering base, still further strengthen the resemblance between the two seeds.

1 B. Renault, Bassin houiller et permien d'Autun et d'Épinac, p. 399. 


\section{Comparison with Cycads.}

Recent work on the Cycadean ovule, ${ }^{1}$ and the additional facts regarding the structure of Trigonocarpiss here brought forward, serve to emphasize the unmistakable relationship between the two groups. In the organization of the integument, differentiated into three layers, the agreement is extremely close, even as regards the broad structure of the stony layer which in Cycads as well as in Trigonocarpus is formed of longitudinally directed fibres on the inside, which at the outside become interwoven with horizontally directed elements. ${ }^{2}$ Also, in the vascular organization and the structure of the pollen chamber ${ }^{3}$ the resemblances are particularly evident.

The chief interest of the present work in this connexion results from the recognition of the short Cycadean type of sclerotic beak within the genus Trigonocarpus, and the presence of secretory elements situated in the sarcotesta of the latter, and resembling very closely the mucilage sacs of the modern group.

The tendency for the non-vascular ribs to die out, of which an early stage is shown by $T$. Shorensis, reaches its culmination in the Cycadean family, where, too, the development of ribs in relation to the sarcotestal bundles, as found in T. Parkinsoni, likewise constitutes a prominent feature of certain genera.

The absence of a nucellar system in the Lagenostomales is probably correlated with the fusion between testa and nucellus. How, then, are we to account for the retention of this same system under similar conditions in the Cycadean ovule? The explanation seems to be found in the isolation of the nucellar and integumental systems from one another by the intervening sclerotesta, which thus prevents the latter from performing the functions of both.

The suggestion advanced by Worsdell ${ }^{4}$ that the fused integument and nucellus was brought about by a congenital fusion rather than that it arose as an intercalated zone of growth, as suggested by F. W. Oliver, ${ }^{5}$ seems the more probable, both on the grounds there adduced and in view of the absence of any evidence in Cycads, comparable to that found in the Lagenostomales, of such having taken place.

1 Kershaw : Structure and Development of the Ovule of Bowenia spectabilis. Ann. Bot., vol. xxvi, No. 103, J9I 2.

Stopes: On the Double Nature of the Cycadean Integument. Ann. Bot., vol. rix, 1905, p. 564 ; Chamberlain: The Orale and Fernale Gametophyte of Dioor. Bot. Gaz., rol. xlir, 1906, p. 332 .

Kershaw, loc cit., p. 643 .

- Fasciation, its Meaning and Origin. New Phyt, vol.iv, 1905, p. 38.

s The Orules of the Older Gymnosperms. Ann. Bat., vol. xvii, 1903. 


\section{ViII. General Discussion of the testa.}

\section{The Multiple Origin of the Integument in the Trigonocarpeae.}

The general facts supporting the theory of a multiple origin for the integument of the Lagenostomales are well known, ${ }^{1}$ and in the Trigonocarpean series the integument is also composed of several equivalent units, which may well have had a similar origin. We shall therefore briefly review the chief testal features which the members of this group exhibit.

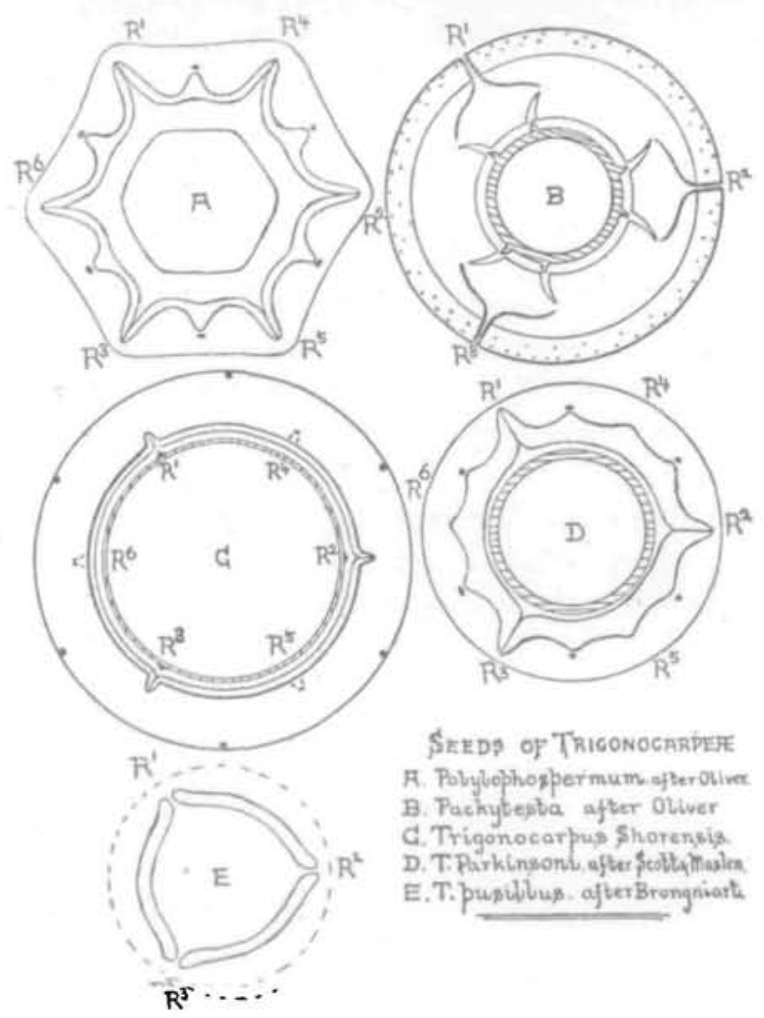

TExT-FIG. 8. Transverse sections of the seeds of varions Trigonocarpeac. Corresponding ribs are in each case marked $R^{1}, \mathbf{R}^{\mathbf{2}}$, \& $\mathrm{c}$.

In the genus Trigonocarpus itself $T$. Parkinsoni had twelve ribs, three primary and fissured, three secondary and non-fissured, and six tertiary, opposite which the - sarcotestal bundles were situated (Text-fig. $8, \mathrm{D})$.

In $T$. corrugalus $^{2}$ and $T$. Shorensis six ribs only were present, of which the three non-commissured died out, about half-way up in the former seed and one-third in the latter (Text-fig. 8, c).

1 Oliver and Salisbury: Palaeozoic Seeds of Conostoma. Ann. Bot., vol. xxv, 19II, p. 4 I.

'Renanlt, loc. cit. 
In $T$. pusillus ${ }^{1}$ the ribs had almost become obsolete and the sclerotesta was nearly circular in outline, with three commissured ribs only very slightly projecting (Text-fig. 8, в).

Polylophospermum ${ }^{2}$ possessed twelve ribs, of which six were fissured, the alternating and non-fissured ribs corresponding to the radial planes of the six sarcotestal. bundles (Text-fig. $8, \mathrm{~A}$ ).

Plycholesia and Hexaplerospermum." Six-angled seeds with very prominent ribs, all of which in the case of the former were fissured (perhaps also in the latter) and enlarged at the ends, owing to the separation of the two parts in that region.

Polyplerospermum.4 An hexagonal seed with six acute ribs at the angles of the testa, and alternating with them six others which were short and blunt.

Pachylesta: A circular seed, but exhibiting, like T. pusillus, three commissures. The bundles had undergone considerable branching, so that not only are they numerous tangentially, but also form two concentric series, a complexity of vascular organization that goes hand in hand with an elaborate internal structure (Text-fig. 8, B).

Stephanospernum. The two species were circular, and all vestiges of ribbing have disappeared. The sarcotesta is usually only represented by the tissue occupying the apical cup, so that its vascular structure is unknown.

The species of Trigonocarpus, we see, thus form a consecutive series involving the gradual elimination of the secondary' ribs.

The production of ribs in relation to bundles is a phenomenon of widespread occurrence, met with elsewhere in the seeds of Dicotyledons, Gnetales, and Cycadales, as well as in the vegetative organs of many plants. They are probably an expression of mechanical utility, and, except from the taxonomic standpoint, the absence of such ribs from the seeds of $T$. Shorensis and $T$. corrugatus is a point of little importance.

Disregarding the vascular ribs, the general sclerotestal structure in Trigonocarpus Shorensis and T. Parkinsoni is identical. Scott and Maslen ${ }^{7}$ remarked on the variability in development of the secondary ribs in the latter species, which always die out before the primary, and in some cases are so slightly developed as to be practically absent. The two species $T$. corrugatus and $T$. Shorensis constitute further stages in the reduction series, for in the former these ribs only extend for half the length of the seed, and in the latter are mere chalazal vestiges. In T. Noeggerathi only the primary ribs are present. And, finally, in species such as $T$. pusillus and $T$. elongatus all indication of the secondary ribs is lost, which applies almost equally to the primary ones also. It is evident that the secondary ridges in the genus Trigonocarpus were in an obsolescent condition, which would fully account for the absence of commissures if such did, as the writer believes, originally exist.

1 F. W. Oliver, New Phyt., vol. iii, I904, pp. 96-104.

F. W. Oliver, Ann. But., vol. $x \times \mathrm{i}, 1907, \mathrm{pp} .303-4$.

3 Brongniart, Comptes rendus, tome lxxviii, 1874, pp. I5a, I6.

- Brongniart, loc. cit., p. $16 . \quad$ F. W. Oliver, New Phyt., vol. i, No. 7, 1902.

: Oliver, Trans. Linn. Soc. Bot., vol. vi, Jg04.

1 Loc. cit., p. 107 . 
F. W. Oliver has called attention to the remarkable resemblance between the plans of T. Parkinsoni and Polylophospermum, ${ }^{1}$ one which is rendered complete if we assume that the secondary ribs of the former were the representatives of originally commissured structures. The conclusion, then, seems warranted that the six ribs of $T$. Shorensis and the non-vascular ribs of T. Parkinsoni are homologous with the six commissured ribs of Polylophospermum (in other respects, of course, this seed is specialized). It is, moreover, probable that the sutures themselves represent the planes of lateral fusion between six originally free members-a view which is further supported by the recognition of six component units in the micropylar region of $T$. Shorensis.

Newberry ${ }^{8}$ has figured a cast showing the apex of a Trigonocarpus with its sarcotesta preserved, and in which the micropylar canal is seen as a star-shaped opening surrounded by six small but free sarcotestal lobes.

We have noted how, in the genus Trigonocarpus, ribs have become completely eliminated and each pair of units fused laterally, so that three sutures only remain. This condition obtains in the genus Pachytesta, and further reduction might well result in the production of a non-commissured seed, as in Stephanospermum.

The remaining genera cited above are either six- or twelve-ribbed seeds, and in the latter case the additional members may well correspond to the six vascular ribs of Polylophospermum.

Other genera there are, belonging to the Radiospermeae, which nevertheless possess ribs that in number are some multiple of two, e.g. Eriotesta, Codonospermum. Our review has, however, shown that there existed a group of seeds agreeing in their internal structure and consistent with our hypothesis in their sclerotestal plan, moreover including all those forms in which an undoubtedly Trigonocarpean organization has been established.

The possible origin of dimerous from trimerous forms is considered in the sequel, but the Radiospermeae is doubtless an artificial aggregate of which the Trigonocarpeae is one of the included natural groups; a statement that is borne out by the constant association with these seeds of the Neuropteridian type of foliage. ${ }^{3}$

None of these genera militate, then, against the theory that the integument originated as a whorl of six free members, each with a single vascular bundle, which subsequently became laterally fused. Such an interpretation necessitates the recognition of the sarcotesta and sclerotesta as constituting a phylogenetically homogenous structure, and in the next section will be given data that amply warrant that conclusion.

A striking feature of the Trigonocarpeae is not only the occurrence

1 Ann. Bot., vol. xxi, 1907, pp. 303-4.

'Rep. Geol. Survey of Ohio, vol. i, Pt. 2, 1873, p. 336 and Pl. XLII, Fig. 5.

'See M. Grand' Eury, Comptes rendus, vol. cxxxix, 1904, p. 3 . 
throughout of the hexamerous type; but also the absence of variation in the individual species. This stereotyped character suggests analogy with present-day Monocotyledons, and is in marked contrast to the variability exhibited by the Lagenostomales, not only as between different genera and species, but also as between individuals. For example, in Physostoma ${ }^{1}$ nearly 50 per cent. of the seeds had ten ribs, but the remainder exhibited from nine to twelve. In Conostoma the number was six or eight according to the species, with one recorded variant of Conostoma oblongum possessing seven. ${ }^{2}$ In Lagenostoma Lomaxi the normal number was nine, ${ }^{3}$ and for $L$. ovoides eight, with variation from six to nine.4 Finally, in Gnetopsis elliptica the number of ribs was four, with perhaps two others vestigial. ${ }^{5}$ In this series we see that there is almost every variation from four up to twelve, and whilst a multiple of three is by no means infrequent-a reminiscence perhaps of relationship to the Trigonocarpeae-the more normal feature is some multiple of two.

Our knowledge of the structure of Conostoma and Gnetopsis has shown how narrow is the dividing line between radiospermy and platyspermy. ${ }^{\circ}$ Also the recent discoveries of Aneimites fertilis ${ }^{6}$ and Pecopteris Plakeneti, ${ }^{7}$ together with the obvious relationships between Pteridosperms and the Cordaiteae, render it necessary to consider the possibility of deriving bilateral forms from a trigonous group. The fact that the fructification Pecopteris Plukeneti was borne on a Medullosean type of foliage certainly indicates such a change, so that the analogy afforded by examples from the carpellary structures of the present-day Flora may not be without value. The Carices are represented in the British Flora by about fifty species, of which over thirty possess three stigmas associated with a triangular nutlet; the remaining species mostly have two stigmas, and the nut is either bilaterally symmetrical or plano-convex. In a few species with two stigmas the nut is slightly trigonous, and in Carex paludosa, Good., the stigmas vary from three to two, accompanying which the nut is either trigonous or lenticular.

As an example from the Dicotyledonous series, the Polygonaceae furnish us with a group in which triangular fruits are the rule. In part of the genus Polygonum, and in the genus Rumex, a triangular nut is associated with three stigmas. In the section Persicaria of the genus Polygonum, and in Oxyria, the fruit is lenticular and composed of only two carpels, as shown by the pair of stigmas.

To come much nearer, the fructifications of Girikgo biloba have been

1 Oliver : Ann. Bot., Igog.

2 Oliver and Salisbury : Ann. Bot, vol. xxv, 1911.

3 Oliver and Scott : Phil. Trans. Roy. Soc, rol. v, 1903, p. 197.

4 Prankerd, T. L. : Jour. Linn. Soc. Bot., vol. xl, No. 278, p. ${ }_{4}^{63}$.

- Oliver and Salisbury, loc. cit.

- Dr, David White: The Seeds of Aneimites. Smithsonian Misc. Coll., vol. xlvii, pt. 3 .

7 M. Grand' Eury, Cómples rendus, vol. cxl, p. 920. 
found with three ribs in place of two, a variation that may even be a reversion.

Such examples suffice to show that the assumption of an originally hexamerous integument (later becoming trimerous in some forms) for the Trigonocarpeae does not preclude the origin of closely allied genera possessing bilaterally symmetrical structures. (The position of the tetramerous Radiosperms awaits details of their internal structure.)

In view of the frequent association in the monocotyledonous series of trimerous flowers with a triangular stem structure, an expression probably of similar mechanical relations, it is of interest to note that the general outline of the stems both of Medullosa anglica and Sucliffia insignis was broadly triangular, ${ }^{1}$ though the character does not of course hold for other species of the former genus.

Before leaving this subject it is of interest to note that Drs. Stopes and Fuji regarded Yesostrobus Oliveri as more nearly approaching to Trigonocarpus than any other known fossil or recent group, ${ }^{2}$ and therefore, on the foregoing hypothesis, the triangular outline which this seed exhibits in transverse section may have a phylogenetic significance.

\section{The Question of a homogeneous or dual Phylogeny.}

The question at once arises in relation to the integument: was this structure of uniform origin or was it dual, as suggested by Stopes for Cycads ? The close agreement of the two groups makes the assumption of a double nature for the one almost necessitate its acceptance for the other. The main grounds on which this theory is based are, briefly, the presence of two series of bundles, both supposed to be integumental, and the resemblances that exist between Lagenostoma with its cupule on the one hand, and the Cycadean ovule with its sarcotesta on the other. The recent work of Miss Kershaw ${ }^{5}$ on Bowenia spectabilis has shown that in this species at least the inner vascular system is nucellar. On the other hand, Dr. Stopes traced some members of the inner vascular system of Cycads into the integument beyond the free part of the nucellus, and unless future work should show that it is only the accessory branches from the integumental system that behave in this manner, the evidence as to the nature of the inner bundles must remain in its present contradictory state. But in view of the diverse data at present available, we are not warranted in attaching any great importance to the occurrence of two systems, even should they prove to be both integumental in certain cases. The branched

1 Scott, Phil. Trans. Roy. Soc., B, rol, cxci, 1899; and Scott : On Sutcliffia insiguis. Trans. Linn. Soc. Bot., vol. iii, 1906, Pt. 4, ser. 2.

- Phil. Trans. Roy. Soc., ser. B, vol, cci, I909. More recently, however, Prof. Fuji has come to regard the nearest living relatives of this plant as being the Araucarieae.

- Loc. cit. Fig. 14

In the Double Nature of the Cycadean Integument. Ann. Bot., 1905.

s Ann. Bot., vol. xxvi, No. 103, 1912, p. 636 . 
and double system of integumental strands in Pachytesta evinces a tendency that might well have subsequently developed, and its origin in consequence have gradually become obscured.

With regard to the second argument in relation to Lagenostoma, recent work has shown that, in spite of the free nucellus exhibited by the Trigonocarpeae, they agree both in the structure of their fructifications and stem anatomy much more closely with the modern group than do the Lagenostomales. ${ }^{1}$

When we turn to Trigonocarpus Shorensis we find that the evidence for a homogeneous origin for the whole integument is abundantly clear. Such inner flesh as is present is but the unsclerized internal lining of the hard shell, and this latter, though broadly composed of an outer and inner part, is formed from one and the same tissue by the different course which its elements pursue.

The sarcotesta on its inner periphery shows a complete transition from the outer sclerotestal cells, so there is no zone to which we can point as possibly representing the fusion plane of two morphological units. And if further evidence were necessary it is furnished by the course of the secretory elements which pass from sclerotesta to sarcotesta irrespective of the differences of texture which, in the mature fruit, these regions present.

\section{The Origin of the Integument in the Trigonocarpeae,} AND THE LAGENOSTOMALES.

The addition of yet another Trigonocarpean seed, showing a welldefined nucellar epidermis, adds to the certainty that the group was characterized by the possession of an extensive free region of the nucellus, to which part the megaspore cavity was almost entirely confined. This would seem to be a fundamental difference separating them off from the other members of the $P$ teridospermeae.

The considerable resemblances which the Trigonocarpeae bear to the Lagenostomales, both as regards the general organization of their seeds and the broad features of anatomy, in the few stems which have been allocated to fructifications, indicate that the two must have had a closely allied ancestry, either in some semi-Pteridospermic group which possessed a generalized type of fructification, giving rise to the characters of both; or in two parallel developments arising independently from the Pteridophytic stock.

The theory of intercalated growth put forward by F. W. Oliver in a similar connexion ${ }^{2}$ to homologize modern with fossil forms, applied in the manner indicated below, seems to offer the best explanation of both the resemblances and differences which these two groups exhibit.

1 Kershaw, loc cit. ; and de Fraine: On Sutcliffa insignis. Ann. Bot., vol. xxvi, rgr 2.

3 The Orules of the Older Gymnosperms. Ann. Bot,, vol, xvii, 1903 . 
In Physostoma, the most archaic type of the Lagenostomales, the megaspore cavity projects into the free portion of the nucellus, the plinth being only slightly developed.

In the more advanced Lagenostoma, the plinth exhibits intercalary growth, so that there is a greater extent of free nucellus in the older than in the younger phase, whilst in Conostoma the plinth reaches its greatest extent.

These facts seem to indicate that the free apical portion of the nucellus was in this series a phylogenetically late development, resulting from a zone of intercalated growth.

On various grounds Physostoma is regarded as the most primitive seed yet known, ${ }^{1}$ therefore it is of greater significance as being the only member of the Lagenostomales exhibiting a free apex of the nucellus into which the megaspore cavity projects. We may therefore suppose that the potentiality for the development of a free nucellus was possessed by the ancestors of Physostoma; but was only exhibited by the majority of the group in the intercalated growth of the region above the contained megaspore, resulting in the elaboration of the plinth.

Probably, then, the common ancestors which gave rise to the Lagenostomales on the one hand and the Trigonocarpeae on the other possessed a nucellus unenclosed at the apex, and round the base of which were fused a. whorl of members with free apical portions, affording protection to the sporangium, in which the prothallus was now retained. With the inception of the seed habit came an increase in the size of the megaspore cavity, accompanying enlargement of the nutritive prothallus. Here is where the divergence in the two lines of descent arose. In the one case there was an upward extension of the megaspore cavity and the surrounding free prointegumental lobes, resulting in the production of a free nucellus which may either have had its origin in an already vascularized sporangium, ${ }^{2}$ or the nucellar system may have arisen in relation to the greater demands upon the water-supply now created.

Along the line of the Lagenostomales the increased dimensions were brought about by a similar phylogenetic intercalation of growth, which took place, however, in the lower part where the whorl of protective members constituting the pro-integument was laterally fused to form a ring around the base of the sporangium. The close proximity of the integumental bundles would account either for the suppression or non-development of a special nucellar system. Such a view would not only explain the intermediate characters exhibited by the archaic Physostoma, but it further accords with the broad features of the testa as seen in the two groups.

A marked characteristic throughout the Lagenostomales is that at the

1 Oliver: Ann. Bot., I909.

Oliver: A Vascular Sporangium. New Phytologist, vol. i, 1902, p. 6o. 
apex of the seed the multiple nature of the integument exhibits itself with almost sudden clearness after it becomes free from the nucellus. In the seeds of the Trigonocarpeae, on the other hand, the component units of the testa are in general equally distinct at the base as at the apex, or even throughout their length. These two conditions seem only explicable on the hypothesis that in the one group lateral fusion was simultaneous throughout, representing in fact the elongation of the free parts, and in the other took place in the 'canopy' and body of the seed at phylogenetically distinct periods.

Our investigation of the present seed has shown us that the external periphery of the integument was circular in outline throughout; in other words, the lobing is only shown superficially at the internal periphery, where it extends from near the base to the apex, though in the body of the seed the six lobes manifest near the chalaza, and reappearing at the micropyle, had become reduced to three.

What is true of this species was, judging from impressions with sarcotesta preserved, true also for its congeners, and may well have been a group character. The Trigonocarpeae were then characterized by an internal lobing almost to the base of the seed, whereas in the Lagenostomales such internal lobing is only to be found in the apical region, so that superficially as well as internally the major part of the integument in the one is to be homologized with the distal extremity in the other.

We have assumed that the ancestral fructification of the two groups possessed a whorl of surrounding members fused at the base between themselves. In both Trigonocarpus Shorensis and Trigonocarpus Parkinsoni the sutures of the primary ribs disappear a little before the floor of the seed cavity is reached.

The structural facts therefore justify the assumption that in both groups there was a phylogenetically earlier lateral fusion of the prointegumental members at the base, followed later by their fusion at the apex.

The congenital fusion of the integument with the contained nucellus was but a matter of time, naturally evinced first in the basal region or zone of earlier lateral fusion. This latter, in the Trigonocarpeae, is wellnigh vestigial, so that a free nucellus resulted, whilst in the Lagenostomates it represents the greater part of the seed body.

Later on in the history of the Trigonocarpeae and their descendants, congenital fusion followed in the upper part, giving us the condition in modern Cycads; though here, as in the more recent Lagenostomales, the apical region has remained permanently free in relation to its specialized structure and functions. 


\section{Relation to Vegetative Organs.}

In two of our series of sections there occur, associated with the seed structures, Medullosean petioles of which portions of as many as three are present in one and the same preparation. This fact would, in the light of present knowledge, ${ }^{1}$ appear of itself significant, and, added to this, numerous secretory elements are present in these petioles which agree in structure with those found in the sarcotestal tissue of Trigonocarpus Shorensis. Each is enclosed by a sheath-like layer of somewhat flattened cells, and the wall surrounding the dark carbonaceous mass in the centre exhibits externally the characteristic longitudinal striations. Both of these features are also exhibited in the stems and petioles of Medullosa anglica.

The individual bundles are collateral in structure, the phloem being represented by an empty space upon which the smallest protoxylem elements abut. The xylem is surrounded by a band of sclerotic fibres in close contact with the tracheides. The xylem exhibits no admixture of parenchymatous elements, so that in all respects the bundles are distinct from those of Rachiopteris Williamsoni, ${ }^{2}$ but agree very closely with those of Myeloxylon. ${ }^{3}$ If, then, the petioles above described really belonged to the plant which bore our seed, the petrifaction known as Myeloxylon probably represents an aggregate of petiolar structures corresponding to at least two species of Trigonocarpean fruits, and possibly in both cases having as their stem a structure of the Medullosa anglica type. In any case, the evidence at present available is against any suggestion that Trigonocarpus Shorensis was the fructification of Sutcliffia insignis, though the above association may be entirely without significance.

The presence of numerous secretory ducts is a feature shared by both the known British Medullosean stems. In the structure of the chalazal bundle, whilst the protoxylems of Trigonocarpus Shorensis appear to be grouped in pairs (a feature of Sutcliffia insignis), in the presence of internal parenchyma and a secretory duct within the xylem our sections of Trigonocarpus Parkinsoni show a closer agreement with that stem.

\section{Diagnosis.}

Trigonocarpus Shorensis, sp. nov.

Locality: Shore Littleborough.

Horizon : Lower Coal Measures.

A radially symmetrical obovoid seed tapering to its insertion and circular in transverse section. Length over $4 \mathrm{~cm}$., width $2.4 \mathrm{~cm}$.

1 Scott, Progressus Rei Botanicae, vol. i, p. 206.

- Seward, Ann. Bot., vol. viii, No. 30, 1894 , p. 208.

- Ibid., vol, vii, I 893, p. I. 
Testa differentiated into two parts:

(a) Sclerotesta (length $2.8 \mathrm{~cm}$., width $\mathrm{I} .5 \mathrm{~cm}$.) produced at the apex into a short triangular beak and bearing six ribs, viz. three principal and commissured extending throughout, and three minor and non-sutured reaching to some $8 \mathrm{~mm}$. from the base. (b) Sarcotesta about $4 \mathrm{~mm}$. in thickness, lacunar in structure with numerous secretory sacs, and six peripherally situated vascular bundles alternating in position with the ribs. Limiting layers containing sclerotic strands. Nucellus free, containing vertically directed secretory sacs, and limited within by vascular tissue forming a continuous lining at the base but above passing into separate bundles.

\section{Summary.}

In the foregoing pages a detailed description is given of the Palaeozoic seed Trigonocarpus Shorensis, of which the chief diagnostic features are summarized in the preceding section.

The sclerotesta differed principally from that of the well-known species in its obovoid form and tapering insertion, the absence of ridges in relation to the vascular bundles, and in the relatively short beak. In the early disappearance of the secondary ribs it resembled closely the external cast of Trigonocarpus corrugatus.

Both sarcotesta and sclerotesta showed considerable complexity, with nevertheless a well-marked transition, such as can only be reconciled with differentiation of the same organic unit. The sclerotesta was built up of fibrous elements longitudinally directed within and without, intertwined in a. complex manner. The sarcotesta was unusually broad, lacunar in structure, and contained numerous secretory sacs comparable to those of Cycads.

The limiting layers were formed of a ground-tissue of parenchyma containing a system of probably anastomosing and tangentially flattened strands of fibres, with secretory sacs like those of the interior. The whole structure in this region approached much more nearly to that of the peripheral layers of a Medullosean petiole than in Trigonocarpus Parkinsoni.

The sarcotesta exhibited no flattening, but was circular in form throughout, whilst an inner flesh was probably only present as an inconspicuous layer within the micropyle.

The vascular system comprised two parts, viz. a sarcotestal and a nucellar.

The most notable feature of the former is the extreme peripheral position occupied by the six mesarch vascular bundles.

The single chalazal bundle had the protoxylem groups just within the periphery, and expanded at the base of the nucellus into a tracheal cup, which was probably formed of twelve laterally fused bands that gradually. 
increased in number to form numerous mesarch lenticular bundles lining the inner limit of the nucellus.

The nucellus was attached at the base to a sclerotic papilla, but was otherwise free from the testa, and its outstanding features were-a welldeveloped and thick-walled epidermal layer; the occurrence of three longitudinal flanges, corresponding with the commissures; and the presence of numerous secretory sacs in the ground-tissue, arranged in radial files.

Two sections of Trigonocarpis Parkinsoni are described which indicate that the chalazal bundle gave off three branches simultaneously, which almost immediately bifurcated to form the six sarcotestal strands.

A comparison with Cycads and allied types leads to the conclusion that Trigonocarpus Shorensis is in several respects a relatively more primitive type than its congeners. In this connexion Trigonocarpus Oliveri is shown to have been an eight-angled seed, and is therefore probably to be excluded from the Trigonocarpeae.

In the general discussion on the testa, the evidence for its homogenous origin is set forth, and the theory is advanced that it had its inception in the lateral fusion of a whorl of six originally free members. The testal structure of the various genera is discussed in the light of this theory.

The resemblances and differences between the Trigonocarpeae and Lagenostomales are shown to be explicable on the hypothesis of intercalated growth, followed by subsequent congenital fusion between the nucellus and integument.

Medullosean petioles associated in the coal-balls with Trigonocarpus Shorensis are briefly described, and resemble Myeloxylon.

\section{EXPLANATION OF PLATES.}

\section{Illustrating Mr. Salisbary's paper on Trigonocarpus Shorensis.}

$\mathrm{R}=$ Owens College, Manchester, Collection; S = University College Collection; D.H.S. = Dr. Scott's Collection.

PLATE IV.

Figs. I-IO, photomicrographs.

Fig. 1. Nearly transverse section through the middle of the seed, showing the three commissural ridges $\left(R^{1}, R^{2}, R^{8}\right)$ and the extensive sarcotesta (st.). The nucellus is seen in part on the right with a ridge near the commissure slightly displaced $(n . f$.$) . The black dots in the sarcotesta are the$ carbonaceous contents of the mucilage sacs. . R. I $16 r, k$. $x$ about 4 .

Fig. 2. Slightly oblique section through the micropyle, showing sarcotesta with secretory sacs (oz.S.). Within the triangular sclerotesta the inner flesh can be faintly seen. $\mathrm{R}, 116 \mathrm{I}, k, \times 2 \cdot 5$. 
Fig. 3. Tangential section through the onter sclerotesta. The band-like aggregates of fibrous cells are seen overlapping $\mathrm{n}$ a plait-like manner ( $f . b$.$) and passing in different directions. S. 3^{2}, g^{\text {. }}$ $\times 60$.

Fig. 4. Slightly oblique transverse section near base of seed; on one side a small projection is seen, representing the termination of a minor rib $\left(r^{1}\right)$. Within is the contracted nucellos (nu.) with secretory sacs in radial files, over which the contracted epidermis has formed ridges. S. $33, c . \quad \times 2$.

Fig. 5. A tangential section through the zone of transition between the sclerotesta (scl.) and the sarcotesta (st.c.). The slightly thickened walls, the elongated form, and the sinuous course of the inner sarcotestal cells are here seen. S. $3^{2}, g . \times 90$.

Fig. 6. An oblique section through the base of the micropyle, showing the extensive unflattened sarcotesta with limiting layers at l.l., and secretory sacs in outer sclerotesta (m.s.). S. $31, i . \quad \times 5$.

Fig. 7. Obliquely longitudinal section through chalazal end of the seed, showing vascalar bundle (v.b.), chalazal papilla (c.p.), and the tapering base of seed. S. 32,c. $\times 2 \frac{1}{2}$.

Fig. 8. Section through extreme apex of sclerotic beak. The sclerotesta is seen to be thinning out rapidly, and at the higher level on the right is only some three elements in width. The sides show a median constriction (m.c.) resulting in a six-lobed structure (m.l.). The inner flesh (i.f.) shows a gradual transition from the sclerotic tissue. R. 1161, e. $\times 28$.

Fig. 9. Oblique section through the base of the seed, passing through all six ribs $\left(\mathbf{R}^{1}, \mathbf{R}^{2}, \mathbf{R}^{8}\right.$, and $\left.r^{1}, r^{4}, r^{3}\right)$. At c.p. the chalazal papilla is seen perforated by the single vascular bundle (v.b.). R. $116 \mathrm{r}, b . \times 4$.

Fig. 10. Tangential section through the periphery of the sarcotegta, showing the lacunae (lac.) separated in places by the superposed peg-like projections of the stellate cells $(p$.$) , and elsewhere by$ the cells proper. S. $3^{2}, h . \times 90$.

\section{PLATE V.}

Figs. I I-20, photomicrographs.

Fig. I I. Vertical section throngh the pollen-chamber wall ( $p . w$.$) , from which the cuticle has$ become separated $(c \kappa$.$) . The shoulder is occupied by thin-walled parenchymatons tissne (sh.). The$ oval bodies are fongal spores (sp.). S. $3^{2}, c . \times 50$.

Fig. I2. Transverse section throngh the sarcotesta with two secretory elements, probably derived by branching, in close contact (m.5.). S. $31 . \times 60$.

Fig. 13. A portion of a transverse section to show the nucellar flange, consisting of perenchymatous tissue ( $* . f$.$) and corresponding in position to a commissural rib (com.). A lenticular nacellar$ strand is seen on the left (v.b.). S. 3i, e. $\times 3^{\circ}$.

\section{Trigonocarpus Parkinsoni.}

Fig. I4. Transverse section through the chalazal bundle of Tigonocarpus Parkinsoni at the level at which the sarcotestal strands $(v b$.$) are given off. At the top one of these has branched into$ two. The central xylem mass (c.xy.) is surrounded by a discontinuous sheath of parenchyma (par.), exterior to which more tracheides ( $(r$.) are seen. A single secretory element (m.s.) occupies a position within the xylem mass. In the space between the bundle and the sclerotesta several more secretory elements are seen and remains of parenchymatous tissue. S. $34, a . \times 90$.

Fig. 15. A single sarcotestal bundle from near the base of Trigonocarows Parkinsoni, showing the dual nature of the xylem. The centre of the strand is occupied by narrow tracheides (n.tr.) surrounded by a parenchyma sheath (par.), and this again is followed by a zone of short broad tracheides (s.tr.). S. 34, b. $\times 90$.

\section{Trigonocarpus Shorensis.}

Fig. 16. Transverse section through the chalazal bundle of $T$. Shorensis. The parenchyma sheath (p.s.) around the bundle and the radially extended tracheides of the outer zone are clearly seen. The protoxylems are seen occupying a position just within these latter. mi.s., mucilage sacs. S. 33,b. $\times 100$.

Fig. 17. Trangverse section through a sarcotestal bundle, showing the thick-walled protoxylem elements ( $p t . x_{.}$), the small elements of the centrifugal xylem ( $\left.f f . x.\right)$, and the large short tracheideg comprising the centripetal $\left(c p_{-} x.\right)$. Touching the bundle on the right is a sclerotic strand of the limiting layers. m.s., mucilage sac. S. $31, i, \times 100$. 
Fig. 18. Oblique section through the chalazal bandle, from the same preparation as Fig. 7 , showing the scalariform thickenings of the tracheides (tr.). scl., sclerotesta. S. $3^{2}, \mathrm{c} . \times 80$.

Fig. 19. Transverse section throngh the limiting layers of the sarcotesta, occupied by several radially extended sclerotic strands (scl.p.) partially displaced by contraction. The sclerotic plate on the extreme left is interrapted by a medianly placed mucilage sac, and both here and in the other here present ( $m . s$.$) the thickened wall stands ont clearly as a transperent zone around the dark$ contents. S. $31, i . \times 100$.

Fig. 20. Transverse section throngh the nucellus from the same preparation as Fig. 4 . The radial file of mucilage sacs ( $m . s$.) are clearly seen, causing corresponding ridges (n.r.) apon the surface of the contracted nucellar epidermis (n.e.). The ground-tissue is occopied by thin-walled parenchymatous tissue (par.), and the inner limit is marked by a zone of tracheides ( $t r$. .). S. $33, c$. $\times 120$. 
Annals of Botary.
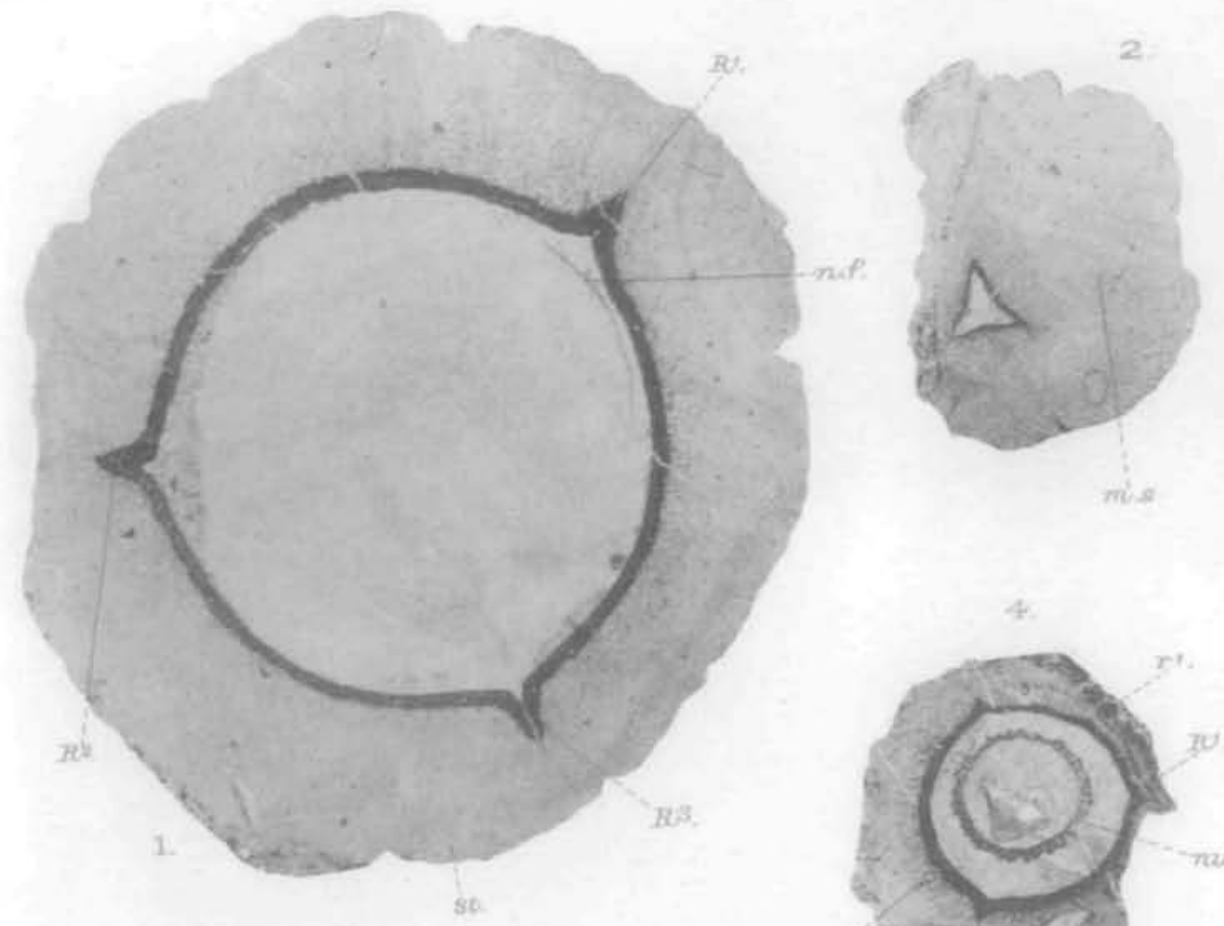

$F: b$

3.
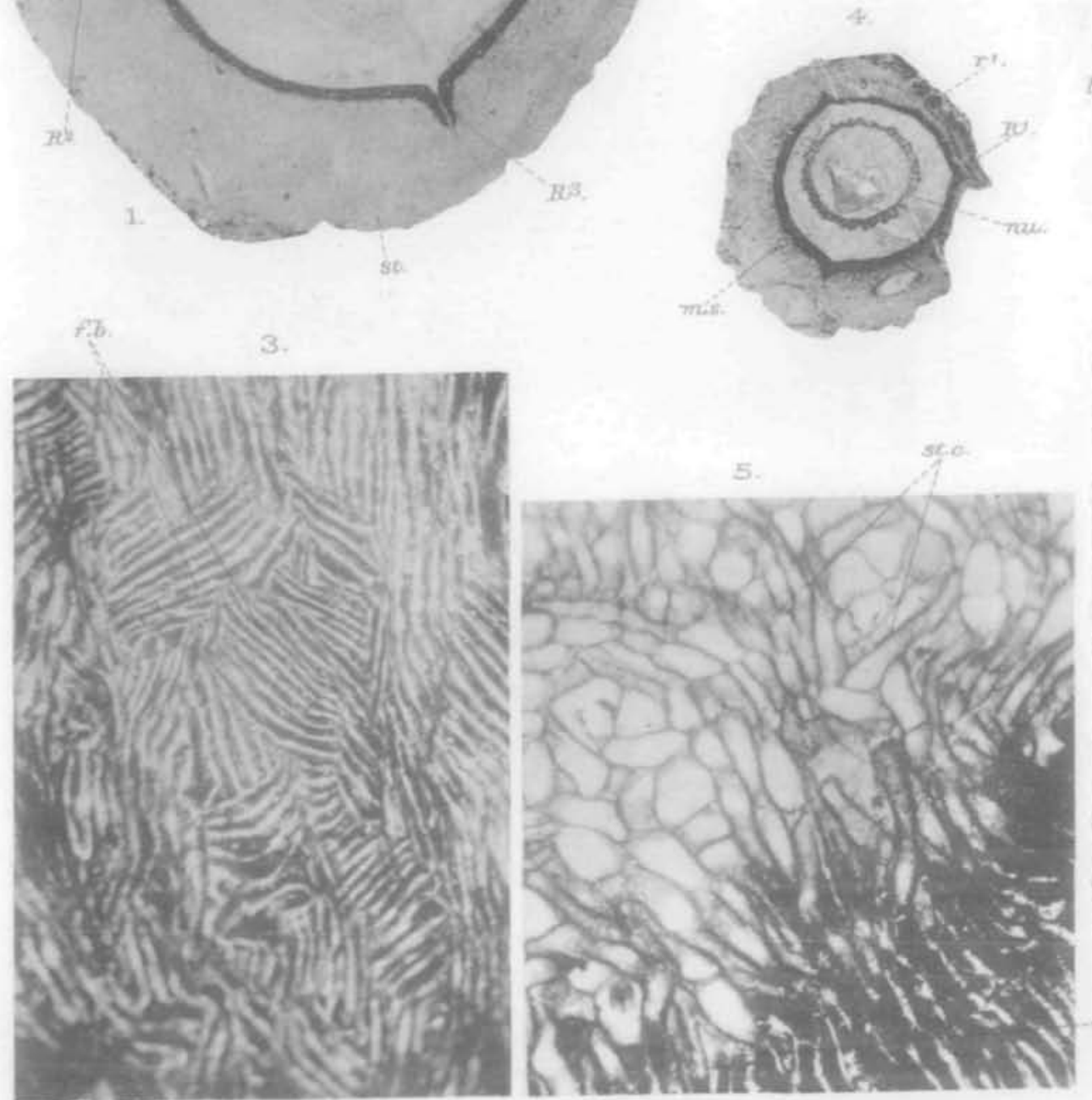

. 
Annals of Botany

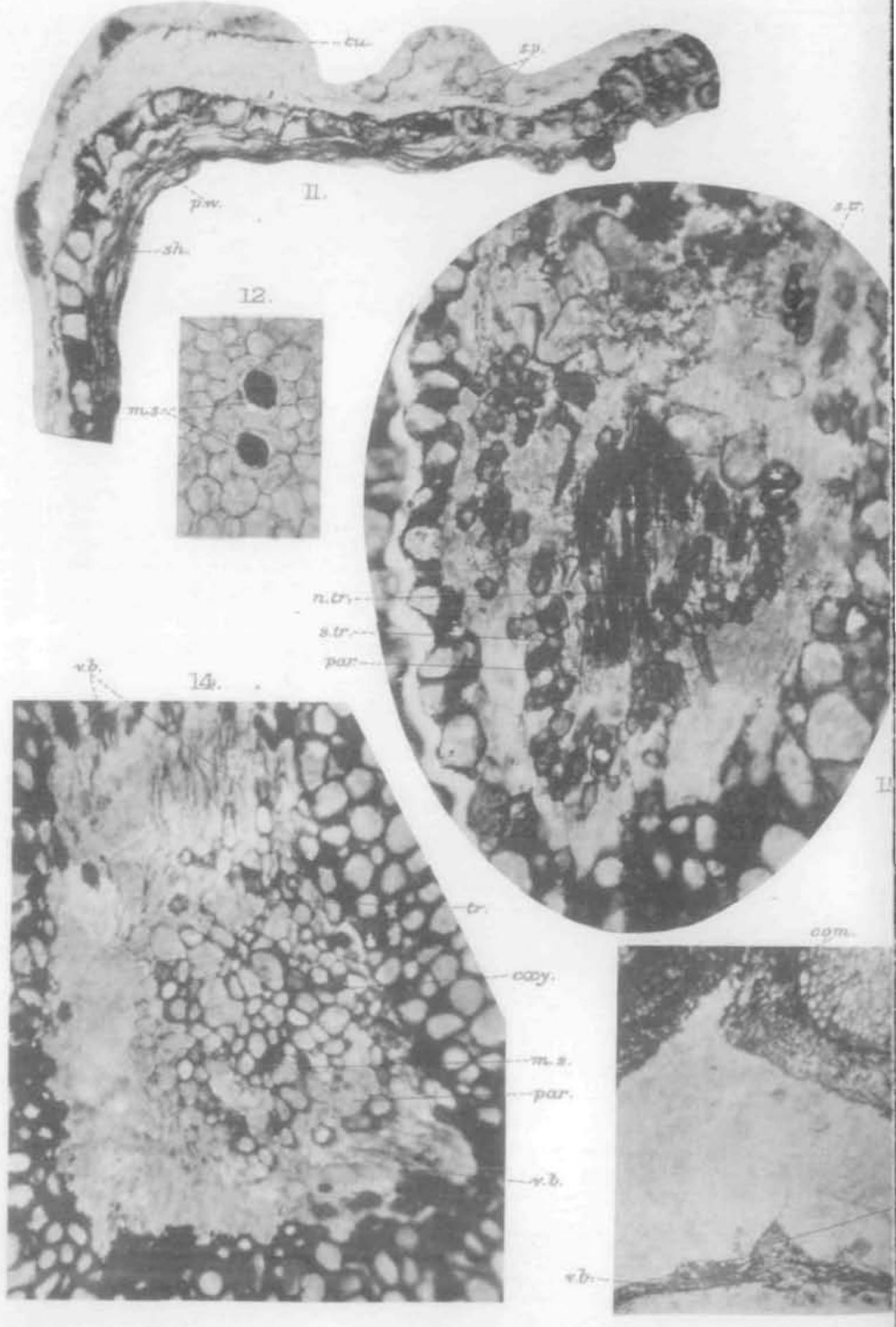




\section{VolXXVIII Pl.V.}

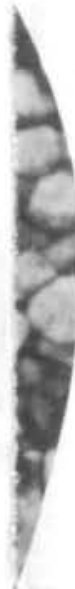

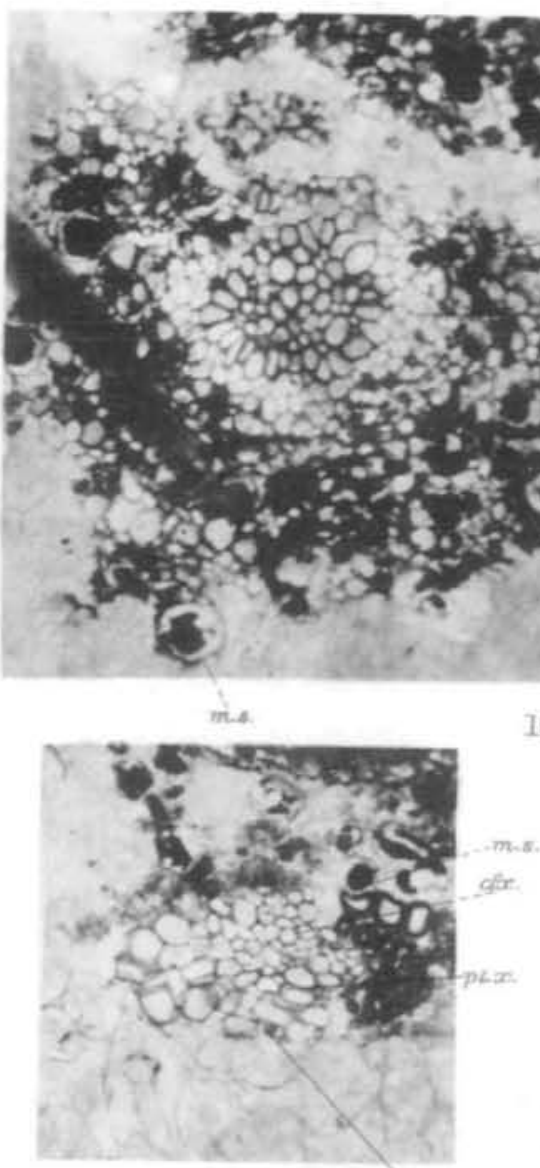

17.

16.
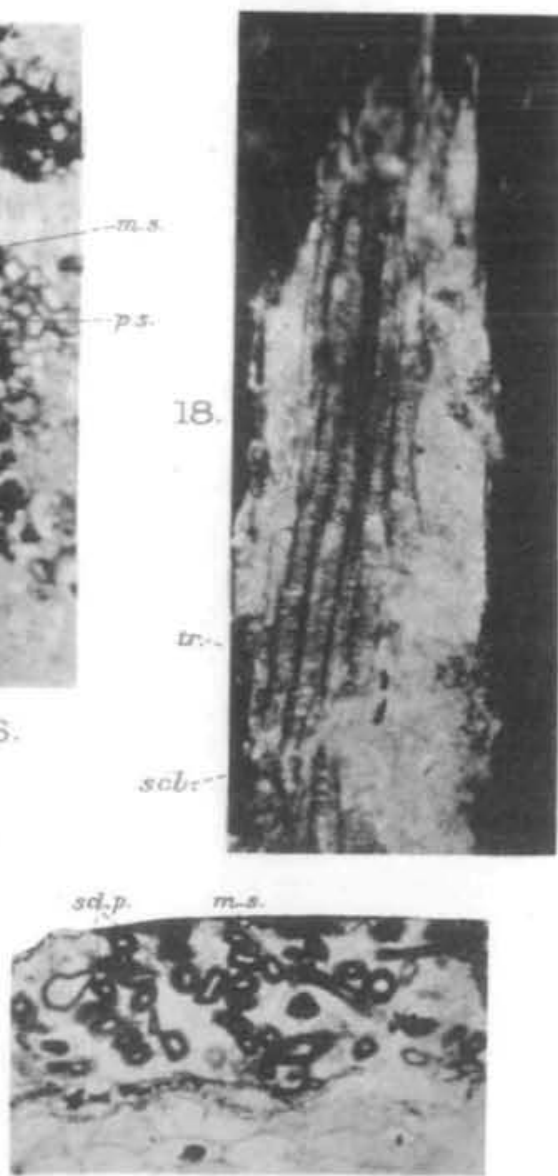

19.

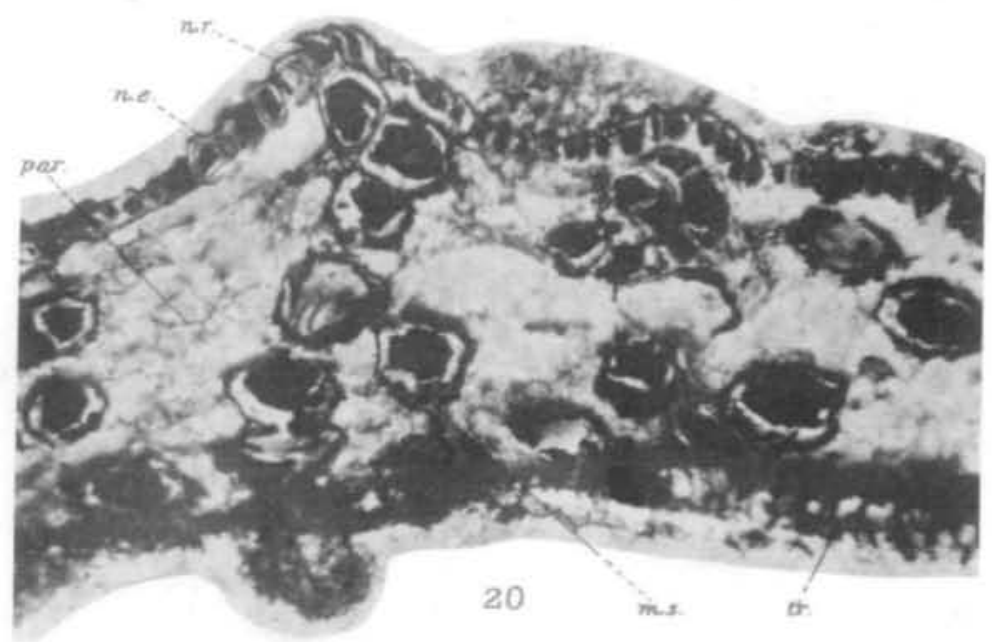

